\title{
Variation patterns in natural populations of wild potatoes along Quebrada de Inca Cueva, northwestern Argentina
}

\author{
V. N. Ispizúa • E. L. Camadro • A. M. Clausen
}

Received: 29 October 2013 / Accepted: 23 June 2014

(C) Springer Science+Business Media Dordrecht 2014

\begin{abstract}
Wild potato species, Solanum infundibuliforme Phil. (ifd) $(2 \mathrm{n}=2 \mathrm{x}=24)$, S. gourlayi Hawkes $(\mathrm{grl})(2 \mathrm{n}=4 \mathrm{x}=48)$ and presumed grl-ifd hybrids $(2 \mathrm{n}=4 \mathrm{x}=48)$ were collected from a narrow gorge known as Quebrada de Inca Cueva, located in Jujuy province, Argentina. To explore the possibility of gene flow and introgression within and between populations and ploidy levels, accessions collected in this gorge and others from neighboring valleys, identified as Solanum oplocense Hawkes (opl), grl and ifd, were characterized according to chromosome number, morphological characters, pollen-pistil relations and seed set following controlled diallelic crosses. Multivariate analysis for 36 morphological characters recorded in individual plants revealed considerable variability. Principal coordinates analysis, revealed that tetraploid populations belonging to presumed hybrids and grl formed a huge swarm in which individuals from different populations appeared intermixed. In one accession (CII 1715), variation in
\end{abstract}

V. N. Ispizúa $(\varangle)$ · E. L. Camadro · A. M. Clausen

Unidad Integrada Facultad de Ciencias Agrarias,

Universidad Nacional de Mar del Plata (UNMdP)-

Estación Experimental Agropecuaria Balcarce, Instituto

Nacional de Tecnología Agropecuaria (INTA), Balcarce,

Buenos Aires, Argentina

e-mail: ispizua.veronica@inta.gob.ar

E. L. Camadro

Consejo Nacional de Investigaciones Científicas y

Técnicas (CONICET), Buenos Aires, Argentina morphological phenotypes in diploid and tetraploids plants were detected, as well as individuals with intermediate characters between the putative parents. The crossing results revealed the action of postzygotic barriers between ifd and presumed hybrids as well as between ifd-opl and grl-opl. These barriers were incomplete as normal seeds were obtained in certain genotypic combinations. In intraspecific crosses and grl $\times$ presumed hybrids crosses, pollen tubes grew normally to the base of the style producing fruits with a variable number of seeds in each. The breeding strategy of these species has resulted in complex mixtures of parental genotypes, advanced hybrid generations and backcrosses in this gorge. The implications of these results for germplasm conservation are discussed.

Keywords Hybridization - Natural populations · Pollen-pistil relations $\cdot$ Solanum gourlayi $\cdot$ Solanum infundibuliforme . Wild potatoes

\section{Introduction}

Solanum L. section Petota Dumortier includes both cultivated and wild potato taxonomic species distributed in the Americas from the southwestern United States to Chile, Argentina, Uruguay, Paraguay and Brazil, with a concentration of diversity in the Andes of South America (Hawkes 1990; Spooner and Hijmans 2001). Phenotypic plasticity, a range of 
ploidy levels from diploid to hexaploid, and hybrid speciation and introgression are common features of these species (Hawkes and Hjerting 1969; Spooner et al. 2004). Hawkes (1990) recognized 232 species, divided into 21 series. Spooner and Hijmans (2001) updated this to 206 species, considering taxonomic changes since 1990. Spooner and Salas (2006) reduced the number further to 189 species for sect. Petota, and Spooner (2009) further reduced the estimate of species for section Petota to 100. The taxonomic status of wild potatoes in South America is currently under revision.

In Argentina, the tuber-bearing species are widely distributed from sea level in Buenos Aires province up to $4,300 \mathrm{~m}$ in the northwestern Andes of Jujuy, and from $22^{\circ}$ lat. $\mathrm{S}$ in the north down to $40^{\circ} 50^{\prime}$ lat. $\mathrm{S}$ in the province of Neuquén (Clausen et al. 2005). As a result of wild potato collections throughout Argentina, there are a considerable number of accessions conserved at the genebank of the Estación Experimental Agropecuaria Balcarce, Instituto Nacional de Tecnología Agropecuaria (INTA).

In a narrow gorge known as the Quebrada de Inca Cueva, Jujuy province, in the northwestern region of Argentina, a swarm of wild potato plants were collected and identified as $S$. infundibuliforme Phil. and S. gourlayi Hawkes; however, several populations presented individuals with intermediate morphology that could not be assigned to any of the two species.

Solanum infundibuliforme (ifd, $2 \mathrm{n}=2 \mathrm{x}=24$; 2EBN) is characterized by slender, usually small plants, easily recognized by narrowly elliptic to linear leaves, with oblique base and broadly decurrent, with interjected leaflets typically absent (Hawkes and Hjerting 1969; Hawkes 1990). In Argentina, its distribution is restricted to the provinces of Jujuy and Salta, in dry rocky areas without vegetation, where ifd plants grow among spiny shrubs or cacti, at the edges of cultivated fields or roadsides, occasionally within cultivated fields, or along river beds, at altitudes of 3,700 to 4,000 m (Clausen et al. 2005).

Solanum gourlayi $(\mathrm{grl}, 2 \mathrm{n}=2 \mathrm{x}=24,2 \mathrm{EBN}$, and $2 \mathrm{n}=4 \mathrm{x}=48,4 \mathrm{EBN}$ ) can be found from central to southern Bolivia and in northwest Argentina (Hawkes and Hjerting 1969; Hawkes 1990). In the latter country, it has been collected at several sites, at altitudes between 2,845 and 3,360 m, where it grows among Bromeliaceae and columnar cacti, on dry and stony hillsides and at the edge of cultivated fields (Clausen et al. 2005). Both diploid and tetraploid cytotypes have been reported for Jujuy province (Clausen and Okada 1987). Solanum gourlayi has received different taxonomic treatments according to Correll (1962), Ugent (1966), Hawkes (1990), Ochoa (1990), van den Berg et al. (1998), Miller and Spooner (1999), Alvarez et al. (2008), based on morphological phenotypes and molecular marker data.

Interspecific hybridization in wild potatoes occurs readily in nature. In fact, Hawkes and Hjerting (1969) hypothesized, on the basis of the complexity of morphological variation patterns, that $9.5 \%$ of the collections examined from Argentina, Brazil, Paraguay and Uruguay were of hybrid origin. Hybrid speciation has been implicated in the formation of species at both diploid and polyploid levels (Okada and Hawkes 1978; Okada and Clausen 1982, 1985; Clausen and Spooner 1998; Rodriguez and Spooner 2009; Rodríguez et al. 2010). According to Spooner et al. (2007), introgression and interspecific hybridization not leading to speciation is believed to be a common cause of much of the taxonomic difficulties encountered in sect. Petota. Masuelli et al. (2009) proposed that recurrent hybridization, in particular interspecific hybridization, acts as a creative evolutionary force in diploid potatoes by releasing variation in natural populations, because it can induce both genetic and epigenetic changes (the latter as a result of genomic stresses).

Elucidation of the underlying causes of the morphological variation patterns observed in the Quebrada de Inca Cueva would be of value in the identification and conservation of germplasm collections as well as in their effective utilization in breeding programs. Therefore, the aim of the present work was to characterize the collections from the site according to chromosome number, morphological phenotypes, pollen-pistil relations and seed set in controlled crosses, in order to explore breeding relations and the possibility of gene flow and introgression within and between populations and ploidy levels.

\section{Materials and methods}

Plant materials

Twelve accessions were collected in January 2005 in Quebrada de Inca Cueva, located in Jujuy province. Only plantlets and tubers were collected as no fruit set was observed at the time of collection. Four accessions 
from natural populations sampled in neighboring valleys, two of S. oplocense Hawkes (opl) and one of ifd collected during January 2005 field trip, and one of grl from a previous collecting trip and conserved in the genebank, were also included in this study (Table 1). The plantlets were cultivated in an insectproof screenhouse at the genebank of the Instituto Nacional de Tecnología Agropecuaria (INTA), Estación Experimental Agropecuaria Balcarce.

\section{Morphological characterization}

At flowering, thirty-six morphological characters were measured (Table 2) in 7-15 plants per accession, except in CII 1714, because only two plants were obtained. Twenty-eight of these characters were quantitative and eight qualitative. Leaf measurements were performed on the fourth leaf from the base of the plant and floral characters were recorded in the first inflorescence.

\section{Statistical analyses}

Phenetic analysis was performed by using the statistical InfoStat software package (Di Rienzo et al. 2008). Two types of matrices were generated; in one of them, each operative taxonomic unit (OTU) was an individual plant, whereas in the other, each OTU was an accession (expressed as the average value of all plants within the accession for each character). Principal coordinates analysis (PCoordA) was performed with the similarity matrix using Gower coefficient (1971) for both qualitative and quantitative data. Principal component analysis (PCA) was carried out for the quantitative data by considering the average value of all plants within an accession for each character. Cophenetic matrices, constructed with Cophenetic Values computed for each analysis, were compared with the original matrix using the Mantel matrix correspondence test.

\section{Reproductive behaviour}

Interspecific and intraspecific crosses were made following an incomplete diallel mating design. Two to six flowers were hand-pollinated per genotypic combination. The number of genotypic combinations performed was determined by the synchrony of

Table 1 Potato taxa and accessions examined, with geographical localization and chromosome numbers

\begin{tabular}{|c|c|c|c|c|c|}
\hline Species & Accession & Department-locality & $\begin{array}{l}\text { Latitude- } \\
\text { longitude }\end{array}$ & $\begin{array}{l}\text { Altitude } \\
\text { (ml.a.s.l.) }\end{array}$ & $\begin{array}{l}\text { Chromosome } \\
\text { number }\end{array}$ \\
\hline S. gourlayi & ClI 1707 & Humahuaca-Quebrada de Inca Cueva & $23^{\prime} 00^{\circ}-65^{\prime} 27^{\circ}$ & 3,650 & $2 n=4 x=48$ \\
\hline S. gourlayi-infundibuliforme $e^{\mathrm{a}}$ & ClI 1708 & Humahuaca-Quebrada de Inca Cueva & $23^{\prime} 00^{\circ}-65^{\prime} 27^{\circ}$ & 3,650 & $2 n=4 x=48$ \\
\hline S. gourlayi-infundibuliforme $e^{\mathrm{a}}$ & CII 1709 & Humahuaca-Quebrada de Inca Cueva & $23^{\prime} 00^{\circ}-65^{\prime} 27^{\circ}$ & 3,650 & $2 n=4 x=48$ \\
\hline S. gourlayi & CII $1710^{\mathrm{b}}$ & Humahuaca-Quebrada de Inca Cueva & $23^{\prime} 00^{\circ}-65^{\prime} 27^{\circ}$ & 3,650 & $2 n=4 x=48$ \\
\hline S. gourlayi-infundibuliforme $e^{\mathrm{a}}$ & CII $1711^{\mathrm{b}}$ & Humahuaca-Quebrada de Inca Cueva & $23^{\prime} 00^{\circ}-65^{\prime} 27^{\circ}$ & 3,650 & $2 n=4 x=48$ \\
\hline S. gourlayi-infundibuliforme $e^{\mathrm{a}}$ & CII 1712 & Humahuaca-Quebrada de Inca Cueva & $23^{\prime} 00^{\circ}-65^{\prime} 27^{\circ}$ & 3,676 & $2 n=4 x=48$ \\
\hline S. gourlayi-infundibuliforme $e^{\mathrm{a}}$ & ClI 1713 & Humahuaca-Quebrada de Inca Cueva & $23^{\prime} 00^{\circ}-65^{\prime} 27^{\circ}$ & 3,676 & $2 n=4 x=48$ \\
\hline S. gourlayi-infundibuliforme $e^{\mathrm{a}}$ & ClI 1714 & Humahuaca-Quebrada de Inca Cueva & $23^{\prime} 00^{\circ}-65^{\prime} 27^{\circ}$ & 3,673 & $2 n=4 x=48$ \\
\hline S. gourlayi-infundibuliforme $e^{\mathrm{a}}$ & ClI $1715^{\mathrm{b}}$ & Humahuaca-Quebrada de Inca Cueva & $22^{\prime} 59^{\circ}-65^{\prime} 27^{\circ}$ & 3,659 & $\begin{array}{l}2 \mathrm{n}=4 \mathrm{x}=48 \\
2 \mathrm{n}=2 \mathrm{x}=24\end{array}$ \\
\hline S. gourlayi-infiundibuliforme $\mathrm{a}^{\mathrm{a}}$ & CII $1716^{\mathrm{b}}$ & Humahuaca-Quebrada de Inca Cueva & $22^{\prime} 59^{\circ}-65^{\prime} 27^{\circ}$ & 3,659 & $2 n=4 x=48$ \\
\hline S. infundibuliforme & CII $1717^{\mathrm{b}}$ & Humahuaca-Quebrada de Inca Cueva & $22^{\prime} 59^{\circ}-65^{\prime} 27^{\circ}$ & 3,653 & $2 n=2 x=24$ \\
\hline S. gourlayi & ClI $1718^{\mathrm{b}}$ & Humahuaca-Quebrada de Inca Cueva & $22^{\prime} 59^{\circ}-65^{\prime} 27^{\circ}$ & 3,653 & $2 n=4 x=48$ \\
\hline S. oplocense & ClI $1705^{\mathrm{b}}$ & Humahuaca-Coctaca & $23^{\prime} 11^{\circ}-65^{\prime} 19^{\circ}$ & 3,070 & $2 n=6 x=72$ \\
\hline S. oplocense & ClI $1706^{\mathrm{b}}$ & Humahuaca-Coctaca & $23^{\prime} 11^{\circ}-65^{\prime} 19^{\circ}$ & 3,046 & $2 n=6 x=72$ \\
\hline S. infundibuliforme & CII 1720 & Humahuaca-Quebrada de Hornaditas & $23^{\prime} 03^{\circ}-65^{\prime} 24^{\circ}$ & 3,592 & $2 n=2 x=24$ \\
\hline S. gourlayi & Oka 4314 & Tumbaya-Quebrada de la Est. Grande & $23^{\prime} 37^{\circ}-65^{\prime} 32^{\circ}$ & 3,200 & $2 n=4 x=48$ \\
\hline
\end{tabular}

Collectors: ClI = Clausen, A. M.; Ispizúa, V. N.; Oka = Okada A.K.

${ }^{\text {a }}$ Presumed $S$. gourlayi-S. infundibuliforme hybrids

b Accessions used for the genetic study 
Table 2 Morphological characters and character states used in the phenetic analysis

\begin{tabular}{|c|c|}
\hline No. & Character (units and scales) \\
\hline 1 & Stem height $(\mathrm{cm})$ \\
\hline 2 & $\begin{array}{l}\text { Stem pigmentation (1) green, (2) green with } \\
\text { purple spots, (3) purple }\end{array}$ \\
\hline 3 & Stem wing (1) presence, (0) absence \\
\hline 4 & Leaf length $(\mathrm{cm})$ \\
\hline 5 & Leaf width $(\mathrm{cm})$ \\
\hline 6 & Terminal leaflet length $(\mathrm{cm})$ \\
\hline 7 & Terminal leaflet width $(\mathrm{cm})$ \\
\hline 8 & Petiole terminal leaflet length $(\mathrm{cm})$ \\
\hline 9 & Primary lateral leaflet length $(\mathrm{cm})$ \\
\hline 10 & Primary lateral leaflet width $(\mathrm{cm})$ \\
\hline 11 & Petiole primary lateral leaflet length $(\mathrm{cm})$ \\
\hline 12 & Secondary lateral leaflet length $(\mathrm{cm})$ \\
\hline 13 & Secondary lateral leaflet width $(\mathrm{cm})$ \\
\hline 14 & Number of lateral leaflet pairs \\
\hline 15 & Number of interjected leaflets \\
\hline 16 & $\begin{array}{l}\text { Base of terminal leaflet (1) cuneate, (2) cordate, } \\
\text { (3) truncate }\end{array}$ \\
\hline 17 & $\begin{array}{l}\text { Density of adaxial pubescence (0) glabrous, (2) } \\
\text { intermediate, (3) dense }\end{array}$ \\
\hline 18 & $\begin{array}{l}\text { Density of abaxial pubescence (0) glabrous, (2) } \\
\text { intermediate, (3) dense }\end{array}$ \\
\hline 19 & $\begin{array}{l}\text { Leaf midrib pigmentation: (0) green, (1) purple } \\
\text { in axils of midrib and secondary veins, ( } 2) \\
\text { purple }\end{array}$ \\
\hline 20 & Leaf colour (1) green, (2) glaucous \\
\hline 21 & $\begin{array}{l}\text { Degree of decurrency of primary lateral leaflet } \\
(\mathrm{mm})\end{array}$ \\
\hline 22 & Peduncle length $(\mathrm{cm})$ \\
\hline 23 & Number of branches of the peduncle \\
\hline 24 & Pedicel length $(\mathrm{cm})$ \\
\hline 25 & $\begin{array}{l}\text { Distance from base of peduncle to articulation } \\
(\mathrm{cm})\end{array}$ \\
\hline 26 & Number of flowers per inflorescence \\
\hline 27 & Calyx length $(\mathrm{cm})$ \\
\hline 28 & Calyx acumen length (mm) \\
\hline 29 & Corolla radius $(\mathrm{cm})$ \\
\hline 30 & Petal lobe width $(\mathrm{cm})$ \\
\hline 31 & Petal lobe length $(\mathrm{cm})$ \\
\hline 32 & Corolla acumen length (mm) \\
\hline 33 & Corolla colour \\
\hline 34 & Anther length (mm) \\
\hline 35 & Style length $(\mathrm{cm})$ \\
\hline 36 & Style exsertion (mm) \\
\hline
\end{tabular}

flowering and the number of available flowers per plant. To study pollen-pistil compatibility relations, styles were removed from the plants $48 \mathrm{~h}$ after pollination and fixed in FAA (8:1:1, v/v/v, $70 \%$ ethanol: glacial acetic acid: $40 \%$ formaldehyde). Ovaries were left on the plants for fruit and seed formation, and an aqueous solution of 4 ppm 2-4D (Dionne 1958) was applied on each of them, to prevent premature abscission. Fixed pistils were rinsed with tap water, treated with an $8 \mathrm{~N}$ solution of $\mathrm{NaOH}$ for $6 \mathrm{~h}$, rinsed again and stained with an aqueous solution of aniline blue in $0.1 \mathrm{~N}$ of $\mathrm{K}_{3} \mathrm{PO}_{4}$ for $4 \mathrm{~h}$ (Martin 1958), mounted in one drop of glycerine on a glass slide, squashed with a cover slip and observed by fluorescence microscopy. Fruits, if any, were harvested at maturity and the number of plump seeds/fruit was recorded. For the compatibility studies, four sites of observation were defined: stigmatic surface, first third of the style, second third of the style and base of the style.

Chromosome counts were performed in tuber roots of a sample of genotypes of each accession, following the standard technique of pre-treatment with an 8-hydroxyquinoline solution $(0.49 \mathrm{~g} / \mathrm{l})$, fixation in 3:1 (v/v absolute ethanol: glacial acetic acid) for $24 \mathrm{~h}$, hydrolysis in $1 \mathrm{~N} \mathrm{HCl}$ at $60{ }^{\circ} \mathrm{C}$ for $10^{\prime}$, staining with leucobasic fuchsin (Coleman 1938) for $4 \mathrm{~h}$ in the dark and squashing with a cover slip on a glass slide.

\section{Results}

The collection site

Along the Quebrada de Inca Cueva, potato plants were found growing in various microsites: the sandy river bed, under bushes, near the caves or along stony walls. Therefore, in sampling populations, we applied the stratified random sampling procedure as recommended for natural populations of wild species (Brown and Marshall 1995). As a result, the distance between sampled populations was variable, ranging from 20 to $300 \mathrm{~m}$. The gorge is highly disturbed, as a result of the presence of grazing animals and the erosion caused by Chulín River.

The number of plants collected at each site depended on the size of each population; it ranged 
from 23 to 62 (in one population only five plants were collected). In some populations we could not meet the goal of sampling 50 plants at each site as recommended by Brown and Marshall (1995).

\section{Statistical analyses}

The morphological analysis revealed that the accessions identified as $S$. oplocense from Coctaca (CII 1706 and CII 1705, 2n=6x =72) clearly separated from ifd $(2 n=2 x=24)$ as well as from accessions from Inca Cueva and Quebrada de Estancia Grande $(2 \mathrm{n}=4 \mathrm{x}=48)$ (Fig. 1$)$. In the analysis of individual plants (PCoordA), factors 1 and 2 accounted for 18.4 and $9.3 \%$ of the total variation. The cophenetic value was 0.81 indicating a good representation of the similarity matrix by the PCoordA.

The accessions of ifd were placed in the upper left quadrant close to some individuals belonging to $\mathrm{ClI}$
1715. This latter accession was composed of diploid $(2 \mathrm{n}=2 \mathrm{x}=24)$ and tetraploid $(2 \mathrm{n}=4 \mathrm{x}=48)$ individuals that were scattered along two other quadrants, intermixed with individuals belonging to the other accessions. These individuals were morphologically very different, resembling either ifd or grl, whereas others presented intermediate characters between the two taxonomic species (Fig. 2). Most accessions from Inca Cueva formed a huge swarm, with extensive overlapping of individuals from different accessions placed in the intersection between the two coordinates. Individual plants of grl, Oka $4314(2 \mathrm{n}=4 \mathrm{x}=48)$ from Tumbaya department, Quebrada de la Estancia Grande, grouped with the tetraploid accessions from Quebrada de Inca Cueva in the upper part of the quadrant.

Principal component analysis was performed considering the average value of all plants within an accession (Fig. 3). In this analysis, accessions

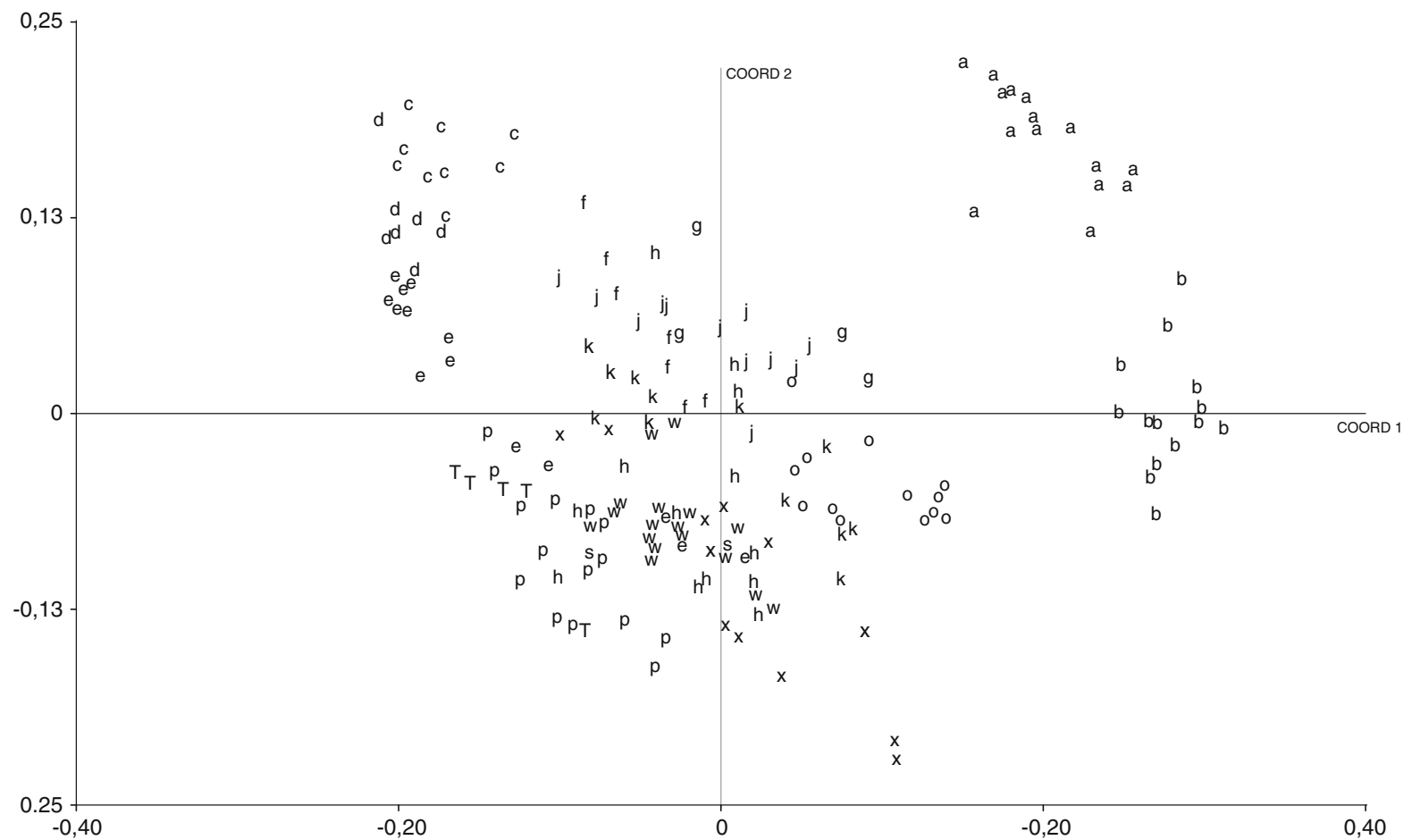

Fig. 1 Principal coordinates analysis of $S$. gourlayi, presumed S. gourlayi-S. infundibuliforme hybrids, $S$. infundibuliforme and S. oplocense, based on 36 morphological characters. Accessions symbols are: $a$ CII 1706 (opl); $b$ ClI 1705 (opl); $c$ ClI 1720 (ifd); $d$ ClI 1717 (ifd); $e$ CII 1715 (grl-ifd); $f$ ClI 1712 (grl-ifd); $g$ Oka
4314 (grl); $h$ ClI 1708 (grl-ifd); $j$ ClI 1710 (grl); $k$ CII 1707 (grl); $\times$ ClI 1713 (grl-ifd); $o$ ClI 1709 (grl-ifd); $p$ ClI 1716 (grl-ifd); $s$ ClI 1714 (grl-ifd); T ClI 1718 (grl); $w$ CII 1711 (grl-ifd) 


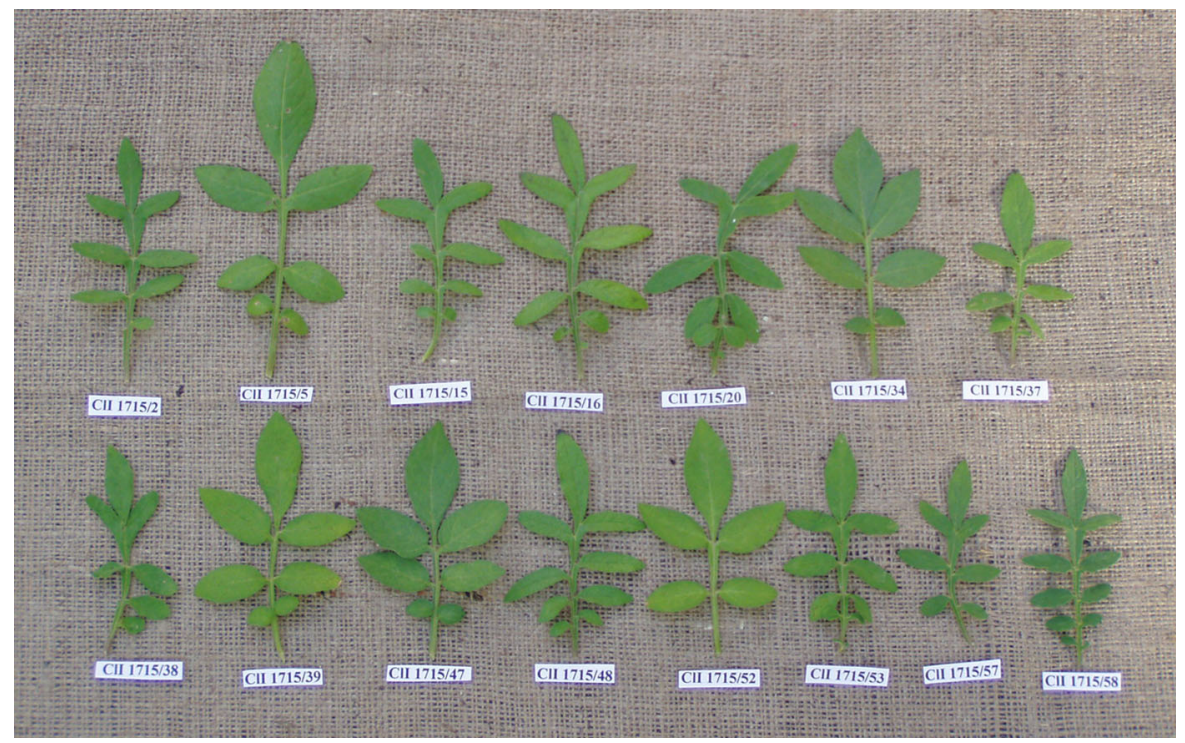

Fig. 2 Morphological variation in leaves of different plants of population CII 1715

identified as ifd were clearly placed in the left lower quadrant whereas the majority of the accessions from Quebrada de Inca Cueva were placed in the intersection of the two axes and in both upper quadrants. Accession CII 1715 was placed outside the range of the tetraploid populations. The first component explained $26.5 \%$ of the total variation and the largest contribution was made by quantitative characteristics of the leaf: secondary lateral leaflet width, leaf width, petiole of primary lateral leaflet length, petiole of terminal leaflet length and primary lateral leaflet width, leaflet length and primary lateral leaflet length. The second principal component accounted for $23 \%$ of the variation and was mostly due to characters of reproductive structures: petal lobe width, style length, petal lobe length, corolla radius, style exsertion and acumen of corolla length. The cophenetic value was 0.83 .

\section{Reproductive behaviour}

A total of 279 genotypic combinations were carried out. The number of combinations performed per species or presumed grl-ifd hybrid was determined by the synchrony of flowering and the number of flowers available per accession.
Intraspecific crosses

\section{Solanum infundibuliforme}

$$
\begin{aligned}
& \text { ClI } \quad \begin{array}{l}
1715 \\
(2 \mathrm{n}=2 \mathrm{x}=24)
\end{array} \quad(2 \mathrm{n}=2 \mathrm{x}=24) \times \text { CII }
\end{aligned}
$$

Six plants from CII 1715 were reciprocally crossed to five plants from CII 1717. Normal pollen tube growth towards the base of the style was observed in all combinations carried out in both crossing directions (Table 3). In ClI $1715 \times$ ClI 1717, seven out of 11 genotypic combinations $(63.6 \%)$ produced fruits with a range of 58 to 236 seeds each (average $=136.8$ ). In the reciprocal crosses, eight out of 11 genotypic combinations $(72.7 \%)$ produced fruits with a range of $0-225$ seeds (average $=122.7$ ).

\section{Solanum gourlayi}

$$
\begin{aligned}
& \text { CII } \quad 1710 \quad(2 n=4 x=48) \times \text { CII } \\
& (2 n=4 x=48)
\end{aligned}
$$

Normal pollen tube growth down to the base of the style was observed in all genotypic combinations (Table 4). In the CII $1710 \times$ ClI 1718 crossing direction, eight out of nine genotypic combinations produced fruits, with a range of 20-216 seeds each 


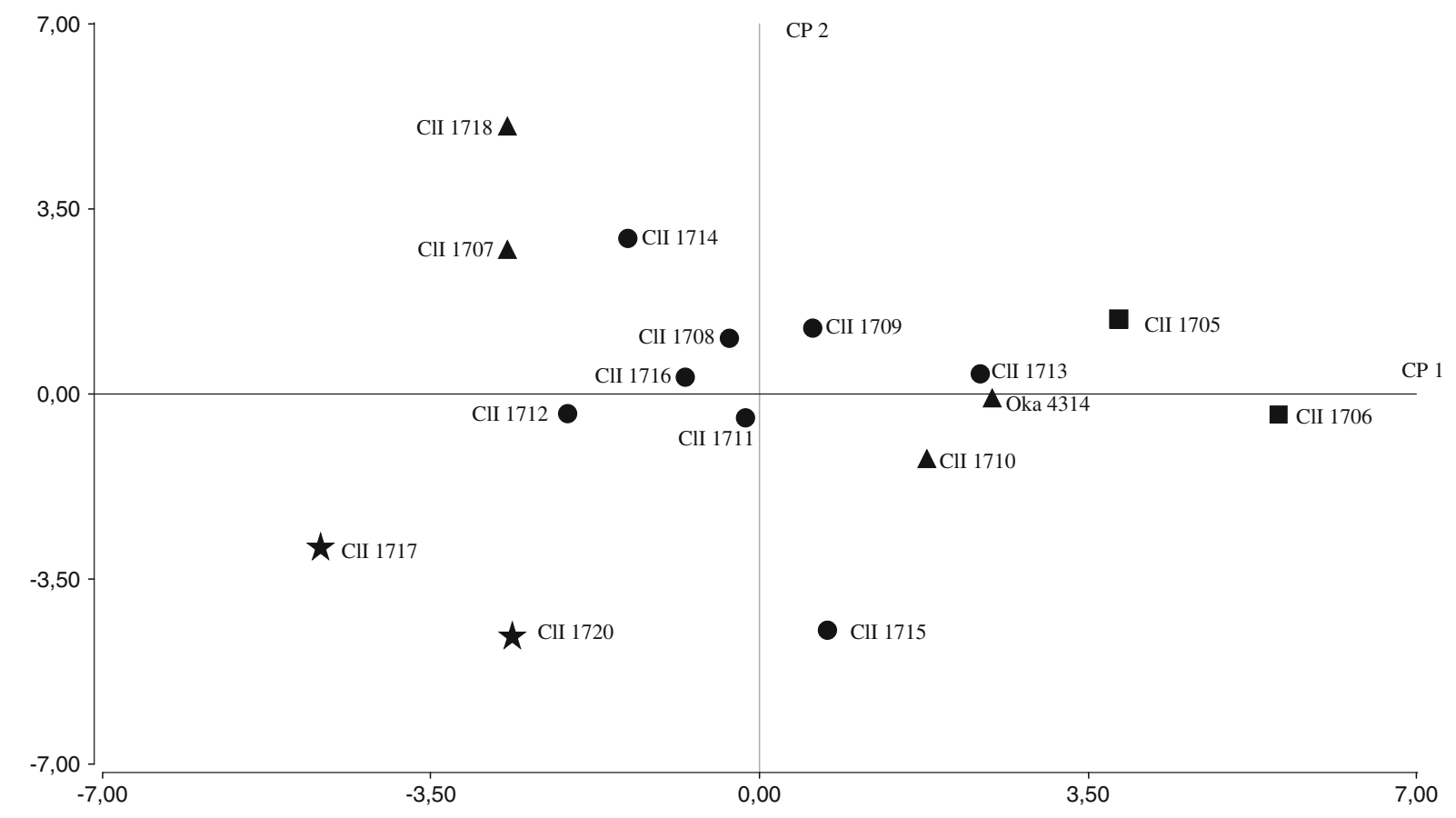

Fig. 3 Principal Component Analysis of circle presumed hybrids, triangle S. gourlayi, square S. oplocense and star S. infundibuliforme based on quantitative morphological characters (average of plants/accession)

Table 3 Number of pollinated flowers, fruits and seeds per fruit and pollen-pistil relations in intraspecific S. infundibuliforme reciprocal genotypic combinations

\begin{tabular}{lllll}
\hline Genotypic combinations & $\begin{array}{l}\text { Pollinated } \\
\text { flowers }\end{array}$ & Fruits & Seeds/fruit & $\begin{array}{l}\text { Pollen-pistil } \\
\text { relations }\end{array}$ \\
\hline $1715 / 2 \times 1717 / 3 / /^{\mathrm{b}}$ & $2 / / 2$ & $2 / / 1$ & $96+128 / / 147$ & $\mathrm{p} 4 / / \mathrm{p} 4$ \\
$1715 / 2 \times 1717 / 11 / /^{\mathrm{b}}$ & $4 / / 3$ & $0 / / 0$ & $-/ /-$ & $\mathrm{p} 4 / / \mathrm{p} 4$ \\
$1715 / 20 \times 1717 / 3 / /^{\mathrm{b}}$ & $4 / / 6$ & $3 / / 4$ & $139+236+143 / / 29+219+125+225$ & $\mathrm{p} 4 / / \mathrm{p} 4$ \\
$1715 / 37 \times 1717 / 8 / /^{\mathrm{b}}$ & $5 / / 5$ & $0 / / 0$ & $-/ /-$ & $\mathrm{p} 4 / / \mathrm{p} 4$ \\
$1715 / 37 \times 1717 / 3 / /^{\mathrm{b}}$ & $6 / / 6$ & $4 / / 1$ & $162+156+172+133 / / 169$ & $\mathrm{p} 4 / / \mathrm{p} 4$ \\
$1715 / 38 \times 1717 / 8 / /^{\mathrm{b}}$ & $5 / / 6$ & $3 / / 4$ & $70+74+215 / / 97+85+78+74$ & $\mathrm{p} 4 / / \mathrm{p} 4$ \\
$1715 / 38 \times 1717 / 4 / /^{\mathrm{b}}$ & $4 / / 4$ & $0 / / 2$ & $-/ / 39+197$ & $\mathrm{p} 4 / / \mathrm{p} 4$ \\
$1715 / 53 \times 1717 / 3 / /^{\mathrm{b}}$ & $6 / / 4$ & $3 / / 4$ & $61+216+141 / / 129+130+139+199$ & $\mathrm{p} 4 / / \mathrm{p} 4$ \\
$1715 / 57 \times 1717 / 3 / /^{\mathrm{b}}$ & $5 / / 3$ & $2 / / 2$ & $162+58 / / 115+136$ & $\mathrm{p} 4 / / \mathrm{p} 4$ \\
$1715 / 57 \times 1717 / 10 / /^{\mathrm{b}}$ & $5 / / 3$ & $2 / / 1$ & $129+110 / / 0$ & $\mathrm{p} 4 / / \mathrm{p} 4$ \\
$1715 / 57 \times 1717 / 11 / /^{\mathrm{b}}$ & $3 / / 3$ & $0 / / 0$ & $-/ /-$ & \\
\hline
\end{tabular}

CII $1715 \times$ CII 1717 crosses

${ }^{a}$ Pollen tube growth until the base of the style (p4)

b Reciprocal crosses 
Table 4 Number of pollinated flowers, fruits and seeds per fruit in intraspecific S. gourlayi reciprocal genotypic combinations

\begin{tabular}{lllll}
\hline Genotypic combinations & $\begin{array}{l}\text { Pollinated } \\
\text { flowers }\end{array}$ & Fruits & Seeds/fruit & $\begin{array}{l}\text { Pollen-pistil } \\
\text { relations }\end{array}$ \\
\hline $1710 / 7 \times 1718 / 2 / /^{\mathrm{b}}$ & $5 / / 6$ & $2 / / 0$ & $20+132 / /-$ & $\mathrm{p} 4 / / \mathrm{p} 4$ \\
$1710 / 11 \times 1718 / 4 / /^{\mathrm{b}}$ & $5 / / 5$ & $2 / / 1$ & $36+25 / / 38$ & $\mathrm{p} 4 / / \mathrm{p} 4$ \\
$1710 / 11 \times 1718 / 5 / /^{\mathrm{b}}$ & $5 / / 5$ & $4 / / 4$ & $104+98+97+84 / / 32+72+73+57$ & $\mathrm{p} 4 / / \mathrm{p} 4$ \\
$1710 / 11 \times 1718 / 3 / /^{\mathrm{b}}$ & $3 / / 5$ & $2 / / 2$ & $216+210 / / 138+122$ & $\mathrm{p} 4 / / \mathrm{p} 4$ \\
$1710 / 14 \times 1718 / 2 / /^{\mathrm{b}}$ & $3 / / 2$ & $3 / / 1$ & $82+165+147 / / 146$ & $\mathrm{p} 4 / / \mathrm{p} 4$ \\
$1710 / 14 \times 1718 / 3 / /^{\mathrm{b}}$ & $4 / / 6$ & $2 / / 2$ & $170+196 / / 36+52$ & $\mathrm{p} 4 / / \mathrm{p} 4$ \\
$1710 / 17 \times 1718 / 6 / /^{\mathrm{b}}$ & $4 / / 5$ & $0 / / 3$ & $-/ / 251+87+126$ & $\mathrm{p} 4 / / \mathrm{p} 4$ \\
$1710 / 21 \times 1718 / 2 / /^{\mathrm{b}}$ & $1 / / 1$ & $1 / / 1$ & $191 / / 86$ & $\mathrm{p} 4 / / \mathrm{p} 4$ \\
$1710 / 21 \times 1718 / 3 / /^{\mathrm{b}}$ & $4 / / 3$ & $3 / / 1$ & $174+164+181 / / 3$ & $\mathrm{p} 4 / / \mathrm{p} 4$ \\
\hline
\end{tabular}

ClI $1710 \times$ ClI 1718 crosses

${ }^{a}$ Pollen tube growth until the base of the style (p4)

b Reciprocal crosses

(average $=131.1)$. In the reciprocal direction, eight out of nine genotypic combinations produced fruits, with 3-251 seeds each (average $=87.9)$.

Interspecific crosses

\section{Solanum infundibuliforme $\times$ presumed (Solanum. infundibuliforme-S. gourlayi) hybrid}

$$
\begin{aligned}
& 1-\text { CII } 1715(2 \mathrm{n}=2 \mathrm{x}=24) \times \text { CII } 1716(2 \mathrm{n}= \\
& 4 \mathrm{x}=48)
\end{aligned}
$$

A total of 30 genotypic combinations were carried out. Normal pollen tube growth down to the base of the style was observed in all genotypic combinations (Table 5). In the ClI $1715 \times$ ClI 1716 crossing direction, ten out of 15 genotypic combinations $(66.6 \%)$ presented problems in seed development. This was revealed by the seedless fruits and fruits with one to four seeds in addition to fruits with 19-22 small seeds that were obtained. In the reciprocal crosses, six out of 15 genotypic combinations (40\%) produced fruits with few or no seeds. Only one combination produced one fruit, with 81 seeds.

$$
\begin{aligned}
& 2 \text {-CII } 1715(2 \mathrm{n}=2 \mathrm{x}=24) \times \text { CII } 1711(2 \mathrm{x}= \\
& 4 \mathrm{x}=48)
\end{aligned}
$$

Normal pollen tube growth down to the base of the style was observed in the CII $1715 \times$ CII 1711 crossing direction (Table 6). Only one combination produced two fruits with 55 and 79 seeds respectively. Fourteen combinations $(77.7 \%$ ) had problems in seed set. In the reciprocal direction, all genotypic combinations had problems in seed set; at the pollen-pistil level, pollen growth was inhibited in the second third of the style in $23.5 \%$ of the combinations and a large number of pollen tubes grew down to the base of the style in $76.5 \%$ of the combinations.

$$
\begin{aligned}
& 3 \text {-CII } 1717(2 \mathrm{n}=2 \mathrm{x}=24) \times \text { CII } 1716(2 \mathrm{n}=2 \mathrm{x} \\
& =48)
\end{aligned}
$$

Six plants from CII 1717 were reciprocally crossed to six plants from ClI 1716 (Table 7). In both crossing directions, two reactions were observed: inhibition of pollen tube growth in the first third of the style and pollen tube growth until the base of the style. In ClI $1717 \times$ ClI 1716 , three out of 13 genotypic combinations $(23 \%)$ produced fruits with 1-40 empty seeds each, eight combinations $(61.5 \%)$ produced seedless fruits and two combinations $(15.4 \%)$ had problems in seed set. In the reciprocal direction, only four combinations (30\%) produced fruits, either with one to four plump seeds each or seedless.

Solanum gourlayi $\times$ presumed $(S$. infundibuliformeS. gourlayi) hybrid

$$
\begin{aligned}
& (2 \mathrm{n}=4 \mathrm{x}=48 \times 2 \mathrm{n}=4 \mathrm{x}=48) \\
& 1 \text {-CII } 1710 \times \text { CII } 1716
\end{aligned}
$$

Normal pollen tube growth to the base of the style was observed in both directions of the cross in all combinations (Table 8). In CII $1710 \times$ CII 1716, nine out of ten genotypic combinations produced fruits with 
Table 5 Number of pollinated flowers, fruits and seeds per fruit in interspecific S. infundibuliforme $\times$ presumed (S. gourlayi-S. infundibuliforme) reciprocal genotypic combinations

\begin{tabular}{|c|c|c|c|c|}
\hline Genotypic combinations & $\begin{array}{l}\text { Pollinated } \\
\text { flowers }\end{array}$ & Fruits & Seeds/fruit & $\begin{array}{l}\text { Pollen-pistil } \\
\text { relations }{ }^{\mathrm{a}}\end{array}$ \\
\hline $1715 / 2 \times 1716 / 38 / /^{\mathrm{b}}$ & $4 / / 3$ & $0 / / 0$ & $-1 /-$ & $\mathrm{p} 4 / / \mathrm{p} 4$ \\
\hline $1715 / 15 \times 1716 / 35 / /^{\mathrm{b}}$ & $5 / / 5$ & $0 / / 0$ & $-1 /-$ & $\mathrm{p} 4 / / \mathrm{p} 4$ \\
\hline $1715 / 37 \times 1716 / 10 / /^{\mathrm{b}}$ & $4 / / 4$ & $1 / / 0$ & $0 / /-$ & $\mathrm{p} 4 / / \mathrm{p} 4$ \\
\hline $1715 / 37 \times 1716 / 37 / /^{\mathrm{b}}$ & $3 / / 2$ & $2 / / 1$ & $0+0 / / 1$ & $\mathrm{p} 4 / / \mathrm{p} 4$ \\
\hline $1715 / 37 \times 1716 / 38 / /^{\mathrm{b}}$ & $6 / / 6$ & $6 / / 2$ & $0+0+0+0+4+0 / / 0+1$ & $\mathrm{p} 4 / / \mathrm{p} 4$ \\
\hline $1715 / 38 \times 1716 / 10 / /^{\mathrm{b}}$ & $4 / / 4$ & $3 / / 2$ & $0+0+0 / / 2+1$ & $\mathrm{p} 4 / / \mathrm{p} 4$ \\
\hline $1715 / 38 \times 1716 / 32 / /^{\mathrm{b}}$ & $5 / / 4$ & $4 / / 0$ & $0+0+0+0 / /-$ & $\mathrm{p} 4 / / \mathrm{p} 4$ \\
\hline $1715 / 38 \times 1716 / 35 / /^{\mathrm{b}}$ & $5 / / 4$ & $0 / / 3$ & $-/ / 0+1+2$ & $\mathrm{p} 4 / / \mathrm{p} 4$ \\
\hline $1715 / 38 \times 1716 / 38 / /^{b}$ & $3 / / 5$ & $2 / / 2$ & $19+2 / / 0+0$ & $\mathrm{p} 4 / / \mathrm{p} 4$ \\
\hline $1715 / 38 \times 1716 / 43 / /^{\mathrm{b}}$ & $4 / / 4$ & $3 / / 0$ & $1+22+0 / /-$ & $\mathrm{p} 4 / / \mathrm{p} 4$ \\
\hline $1715 / 38 \times 1716 / 7 / /^{\mathrm{b}}$ & $4 / / 5$ & $0 / / 1$ & $-/ / 81$ & $\mathrm{p} 4 / / \mathrm{p} 4$ \\
\hline $1715 / 53 \times 1716 / 38 / /^{\mathrm{b}}$ & $4 / / 3$ & $2 / / 0$ & $1+4 / /-$ & $\mathrm{p} 4 / / \mathrm{p} 4$ \\
\hline $1715 / 57 \times 1716 / 35 / /^{\mathrm{b}}$ & $2 / / 3$ & $2 / / 2$ & $1+0 / / 8+1$ & $\mathrm{p} 4 / / \mathrm{p} 4$ \\
\hline $1715 / 58 \times 1716 / 35 / /^{\mathrm{b}}$ & $6 / / 6$ & $0 / / 0$ & $-1 /-$ & $\mathrm{p} 4 / / \mathrm{p} 4$ \\
\hline $1715 / 58 \times 1716 / 43 / /^{\mathrm{b}}$ & $5 / / 5$ & $4 / / 0$ & $22+0+3+3 / /-$ & $\mathrm{p} 4 / / \mathrm{p} 4$ \\
\hline
\end{tabular}

ClI $1715 \times$ CII 1716 crosses

${ }^{a}$ Pollen tube growth until the base of the style (p4)

b Reciprocal crosses

2-201 seeds each (average $=93.1$ ) In the reciprocal crosses, six out of ten combinations produced fruits with 34-294 seeds each (average $=151.6$ ).

\section{2-CII $1718 \times$ CII 1716}

Normal pollen tube growth down to the base of the style was observed in all genotypic combinations, in both crossing directions (Table 9). In ClI $1718 \times \mathrm{ClI}$ 1716, five out of ten combinations produced 15 fruits with 21-198 seeds each (average =77) In the reciprocal crosses, six out of ten combinations produced fruits with 54-285 seeds each (average $=194.7$ ).

\section{S. infundibuliforme $\times$ S. oplocense}

$$
\begin{aligned}
& (2 \mathrm{n}=2 \mathrm{n}=24 \times 2 \mathrm{n}=6 \mathrm{x}=72) \\
& 1 \text {-CII } 1715 \times \text { CII 1705-CII } 1706
\end{aligned}
$$

Seven plants of ClI 1715 were reciprocally crossed to six plants of ClI 1706 and five plants of CII 1705 (Table 10). Two reactions were observed in both crossing directions: inhibition of pollen tube growth in the second third of the style and normal pollen tube growth until the base of the style. In seven of out 14 genotypic combinations, fruits with one to four normal seeds in addition to empty and small seeds, as well as seedless fruits, were obtained when ClI 1715 was used as female parent. In the reciprocal crosses fruits were not obtained in any genotypic combination.

\section{2-CII $1717 \times$ CII 1705-CII 1706}

A total of 30 genotypes combinations were carried out in ClI $1717 \times$ CII 1706 and ClI $1717 \times$ ClI 1705 crosses (Table 11). In nine combinations (60\%), fruits with one to 16 seeds each were obtained in addition to seedless fruits when accession CII 1717 was used as female parent. Two reactions at the pollen-pistil level were observed: inhibition of pollen tube growth in the second third of the style in $12.5 \%$ of the combinations and normal pollen tube growth to the base of the style in $87.5 \%$ of the combinations. In the reciprocal crosses, in which all combinations had problems in seed set, three reactions were observed: pollen grains of heterogeneous size that either did not fluoresce or geminate on the stigma in addition to inhibition of pollen tube growth in the first third of 
Table 6 Number of pollinated flowers, fruits and seeds per fruit in interspecific crosses in $S$. infundibuliforme $\times$ presumed (S. gourlayi-S. infundibuliforme) reciprocal genotypic combinations

\begin{tabular}{|c|c|c|c|c|}
\hline Genotypic combinations & Pollinated flowers & Fruits & Seeds/fruit & $\begin{array}{l}\text { Pollen-pistil } \\
\text { relations }^{\text {a }}\end{array}$ \\
\hline $1715 / 2 \times 1711 / 7 / /^{\mathrm{b}}$ & $3 / / 4$ & $0 / / 0$ & $-/ /-$ & $\mathrm{p} 4 / / \mathrm{p} 4$ \\
\hline $1715 / 15 \times 1711 / 13 / /^{\mathrm{b}}$ & $4 / / 2$ & $2 / / 0$ & $0+0 /-$ & $\mathrm{p} 4 / / \mathrm{p} 3$ \\
\hline $1715 / 15 \times 1711 / 5 / /^{\mathrm{b}}$ & $3 / / 5$ & $1 / / 0$ & $0 / /-$ & $\mathrm{p} 4 / / \mathrm{p} 4$ \\
\hline $1715 / 16 \times 1711 / 7 / /^{\mathrm{b}}$ & $2 / / 2$ & $0 / / 0$ & $-1 /-$ & $\mathrm{p} 4 / / \mathrm{p} 3$ \\
\hline $1715 / 20 \times 1711 / 13 / /^{\mathrm{b}}$ & $3 / / 5$ & $3 / / 0$ & $1+0+4 / /-$ & $\mathrm{p} 4 / / \mathrm{p} 4$ \\
\hline $1715 / 20 \times 1711 / 5 / /^{\mathrm{b}}$ & $5 / / 4$ & $2 / / 2$ & $0+1 / / 0+0$ & $\mathrm{p} 4 / / \mathrm{p} 4$ \\
\hline $1715 / 37 \times 1711 / 5 / /^{\mathrm{b}}$ & $4 / / 4$ & $1 / / 1$ & $0 / / 0$ & $\mathrm{p} 4 / / \mathrm{p} 4$ \\
\hline $1715 / 37 \times 1711 / 6 / /^{\mathrm{b}}$ & $4 / / 3$ & $1 / / 1$ & $0 / / 0$ & $\mathrm{p} 4 / / \mathrm{p} 4$ \\
\hline $1715 / 38 \times 1711 / 5 / /^{\mathrm{b}}$ & $1 / / 5$ & $1 / / 1$ & $0 / / 3$ & $\mathrm{p} 4 / / \mathrm{p} 4$ \\
\hline $1715 / 38 \times 1711 / 7 / /^{\mathrm{b}}$ & $2 / / 5$ & $1 / / 0$ & $0 / /-$ & $\mathrm{p} 4 / / \mathrm{p} 4$ \\
\hline $1715 / 52 \times 1711 / 6 / /^{\mathrm{b}}$ & $3 / / 4$ & $2 / / 0$ & $55+79 / /-$ & $\mathrm{p} 4 / / \mathrm{p} 3$ \\
\hline $1715 / 53 \times 1711 / 5 / /^{\mathrm{b}}$ & $6 / / 4$ & $3 / / 0$ & $1+0+0 / /-$ & $\mathrm{p} 4 / / \mathrm{p} 4$ \\
\hline $1715 / 53 \times 1711 / 6 / /^{\mathrm{b}}$ & $6 / / 5$ & $2 / / 3$ & $1+1 / / 1+0+0$ & $\mathrm{p} 4 / / \mathrm{p} 4$ \\
\hline $1715 / 57 \times 1711 / 6$ & 5 & 1 & 1 & $\mathrm{p} 4$ \\
\hline $1715 / 57 \times 1711 / 13 / /^{\mathrm{b}}$ & $5 / / 5$ & $1 / / 1$ & $1 / / 1$ & $\mathrm{p} 4 / / \mathrm{p} 3$ \\
\hline $1715 / 58 \times 1711 / 5 / /^{\mathrm{b}}$ & $3 / / 4$ & $0 / / 0$ & $-1 /-$ & $\mathrm{p} 4 / / \mathrm{p} 4$ \\
\hline $1715 / 58 \times 1711 / 6 / /^{\mathrm{b}}$ & $2 / / 3$ & $1 / / 1$ & $0 / / 1$ & $\mathrm{p} 4 / / \mathrm{p} 4$ \\
\hline $1715 / 58 \times 1711 / 12 / /^{\mathrm{b}}$ & $5 / / 5$ & $2 / / 2$ & $0+0 / / 1+1$ & $\mathrm{p} 4 / / \mathrm{p} 4$ \\
\hline
\end{tabular}

CII $1715 \times$ CII 1711 crosses

${ }^{a}$ Pollen in the second third of the style (p3); pollen tube growth until the base of the style (p4)

b Reciprocal crosses

style in $28.5 \%$ of the genotypic combinations, inhibition of pollen tube growth in the second third of the style in $42.8 \%$ of the combinations, and normal pollen tube growth down to the base of the style in $14.2 \%$ of the combinations.

\section{Solanum gourlayi $\times$ Solanum oplocense}

$$
(2 \mathrm{n}=4 \mathrm{x}=48 \times 2 \mathrm{n}=6 \mathrm{x}=72)
$$$$
\text { 1-CII } 1718 \times \text { CII 1705-CII } 1706
$$

Four plants from CII 1718 were reciprocally crossed, respectively, to two plants of CII 1705 and three plants of CII 1706 (Table 12). When accession CII 1718 was used as female parent, three reactions were observed: pollen tube growth inhibition in (a) the stigma and (b) the first third of the style, and pollen tube growth until the base of the style. Seventy-five per cent of the genotypic combinations had problems in seed set and, in the remaining $25 \%$ combinations, fruits with normal seeds in addition to empty seeds were obtained. Only one combination produced one fruit, with 174 seeds. In the reciprocal crosses, all genotypic combinations had problem in seed set and two reactions were observed: pollen grains of heterogeneous size that either did not fluoresce or germinate on the stigma, in addition to pollen tube growth inhibition in the first third of style in $87.5 \%$ of the genotypic combinations, whereas normal pollen tube growth until the base of the style was observed in $12.5 \%$ of the combinations.

\section{2-CII 1710 CII 1705-CII 1706}

Normal pollen tube growth down to the base of the style was observed when plants of CII 1710 were crossed as female parents with plants of both CII 1705 and CII 1706 as male parents (Table 13). However, only fruits with empty seeds or fruits with a few normal seeds in addition to empty seeds were produced. In the reciprocal crosses, $82 \%$ of the genotypic combinations had problems in seed set. Two 
Table 7 Number of pollinated flowers, fruits and seeds per fruit in interspecific crosses in $S$. infundibuliforme $\times$ presumed (S. gourlayi-S. infundibuliforme) reciprocal genotypic combinations

\begin{tabular}{lllll}
\hline $\begin{array}{l}\text { Genotypic } \\
\text { combinations }\end{array}$ & $\begin{array}{l}\text { Pollinated } \\
\text { flowers }\end{array}$ & Fruits & Seeds/fruit & $\begin{array}{l}\text { Pollen-pistil } \\
\text { relations }\end{array}$ \\
\hline $1717 / 2 \times 1716 / 7 / /^{\mathrm{b}}$ & $4 / / 4$ & $2 / / 0$ & $0+0 / /-$ & $\mathrm{p} 4 / / \mathrm{p} 4$ \\
$1717 / 4 \times 1716 / 7 / /^{\mathrm{b}}$ & $4 / / 3$ & $1 / / 0$ & $5 / /-$ & $\mathrm{p} 4 / / \mathrm{p} 4$ \\
$1717 / 2 \times 1716 / 32 / /^{\mathrm{b}}$ & $5 / / 6$ & $2 / / 0$ & $0+0 / /-$ & $\mathrm{p} 4 / / \mathrm{p} 4$ \\
$1717 / 4 \times 1716 / 35 / /^{\mathrm{b}}$ & $5 / / 5$ & $1 / / 0$ & $0 / /-$ & $\mathrm{p} 4 / / \mathrm{p} 4$ \\
$1717 / 8 \times 1716 / 35 / /^{\mathrm{b}}$ & $5 / / 5$ & $2 / / 2$ & $8+35 / / 0+1$ & $\mathrm{p} 4 / / \mathrm{p} 4$ \\
$1717 / 11 \times 1716 / 35 / /^{\mathrm{b}}$ & $6 / / 6$ & $0 / / 2$ & $-/ / 0+0$ & $\mathrm{p} 4 / / \mathrm{p} 4$ \\
$1717 / 3 \times 1716 / 38 / /^{\mathrm{b}}$ & $2 / / 3$ & $0 / / 3$ & $0+0 / /-$ & $\mathrm{p} 1 / / \mathrm{p} 4$ \\
$1717 / 8 \times 1716 / 38 / /^{\mathrm{b}}$ & $4 / / 4$ & $2 / / 0$ & $0+0+0 / /-$ & $\mathrm{p} 4 / / \mathrm{p} 1$ \\
$1717 / 10 \times 1716 / 38 / /^{\mathrm{b}}$ & $4 / / 3$ & $3 / / 0$ & $0+0+0 / /-$ & $\mathrm{p} 4 / / \mathrm{p} 4$ \\
$1717 / 11 \times 1716 / 38 / /^{\mathrm{b}}$ & $4 / / 4$ & $3 / / 0$ & $12+40+35 / /-$ & $\mathrm{p} 4 / / \mathrm{p} 1$ \\
$1717 / 3 \times 1716 / 43 / /^{\mathrm{b}}$ & $5 / / 2$ & $3 / / 0$ & $0+0+0+20 / /-$ & $\mathrm{p} 4 / / \mathrm{p} 4$ \\
$1717 / 4 \times 1716 / 51 / /^{\mathrm{b}}$ & $5 / / 5$ & $4 / / 0$ & $0+0+0 / / 0+4$ & $\mathrm{p} 4 / / \mathrm{p} 4$ \\
$1717 / 11 \times 1716 / 51 / /^{\mathrm{b}}$ & $4 / / 4$ & $3 / / 2$ & $\mathrm{p} 4 / / \mathrm{p} 4$ \\
\hline
\end{tabular}

CII $1717 \times$ ClI 1716 crosses

${ }^{\text {a }}$ Pollen tube inhibition in the first third of the style (p1); pollen tube growth until the base of the style (p4)

b Reciprocal crosses

Table 8 Number of pollinated flowers, fruits and seeds per fruit in interspecific crosses in $S$. gourlayi $\times$ presumed $(S$. gourlayiS. infundibuliforme) reciprocal genotypic combinations

\begin{tabular}{lllll}
\hline Genotypic combinations & $\begin{array}{l}\text { Pollinated } \\
\text { flowers }\end{array}$ & Fruits & Seeds/fruit & $\begin{array}{l}\text { Pollen-pistil } \\
\text { relations }\end{array}$ \\
\hline $1710 / 7 \times 1716 / 7 / /^{\mathrm{b}}$ & $4 / / 4$ & $3 / / 2$ & $75+18+12 / / 189+246$ & $\mathrm{p} 4 / / \mathrm{p} 4$ \\
$1710 / 7 \times 1716 / 32 / /^{\mathrm{b}}$ & $4 / / 4$ & $4 / / 4$ & $142+182+201+171 / / 271+294+273+98$ & $\mathrm{p} 4 / / \mathrm{p} 4$ \\
$1710 / 7 \times 1716 / 38 / /^{\mathrm{b}}$ & $3 / / 3$ & $1 / / 0$ & $104 / /-$ & $\mathrm{p} 4 / / \mathrm{p} 4$ \\
$1710 / 11 \times 1716 / 32 / /^{\mathrm{b}}$ & $2 / / 3$ & $1 / / 2$ & $161 / / 176+116$ & $\mathrm{p} 4 / / \mathrm{p} 4$ \\
$1710 / 11 \times 1716 / 51 / /^{\mathrm{b}}$ & $5 / / 5$ & $3 / / 0$ & $95+131+98 / /-$ & $\mathrm{p} 4 / / \mathrm{p} 4$ \\
$1710 / 14 \times 1716 / 7 / /^{\mathrm{b}}$ & $5 / / 5$ & $0 / / 0$ & $-/ /-$ & $\mathrm{p} 4 / / \mathrm{p} 4$ \\
$1710 / 14 \times 1716 / 10 / /^{\mathrm{b}}$ & $4 / / 4$ & $1 / / 0$ & $18 / /-$ & $\mathrm{p} 4 / / \mathrm{p} 4$ \\
$1710 / 17 \times 1716 / 7 / /^{\mathrm{b}}$ & $3 / / 3$ & $2 / / 1$ & $2+79 / / 34$ & $\mathrm{p} 4 / / \mathrm{p} 4$ \\
$1710 / 19 \times 1716 / 38 / /^{\mathrm{b}}$ & $3 / / 4$ & $1 / / 2$ & $83 / / 2+38$ & $\mathrm{p} 4 / / \mathrm{p} 4$ \\
$1710 / 19 \times 1716 / 43 / /^{\mathrm{b}}$ & $5 / / 5$ & $2 / / 2$ & $37+68 / / 162+72$ & $\mathrm{p} 4 / / \mathrm{p} 4$ \\
\hline $\mathrm{C}$ & & & &
\end{tabular}

CII $1710 \times$ CII 1716 crosses

${ }^{\text {a }}$ Pollen tube growth until the base of the style (p4)

b Reciprocal crosses

reactions were observed in the latter: pollen tube growth inhibition in the second third of the style in $35.2 \%$ of the genotypic combinations and normal pollen tube growth down to the base of the style in $47 \%$ of the combinations.

\section{Discussion}

Results obtained in our study provided information about the sampling and collection of wild potato species in the Quebrada de Inca Cueva, the variability 
Table 9 Number of pollinated flowers, fruits and seeds per fruit in interspecific crosses in S. gourlayi $\times$ presumed (S. gourlayi$S$. infundibuliforme) reciprocal genotypic combinations

\begin{tabular}{lllll}
\hline Genotypic combinations & $\begin{array}{l}\text { Pollinated } \\
\text { flowers }\end{array}$ & Fruits & Seeds/fruit & $\begin{array}{l}\text { Pollen-pistil } \\
\text { relations }\end{array}$ \\
\hline $1718 / 1 \times 1716 / 10 / /^{\mathrm{b}}$ & $5 / / 2$ & $3 / / 1$ & $102+139+198 / / 109$ & $\mathrm{p} 4 / / \mathrm{p} 4$ \\
$1718 / 1 \times 1716 / 51 / /^{\mathrm{b}}$ & $3 / / 5$ & $0 / / 3$ & $-/ / 54+184+149$ & $\mathrm{p} 4 / / \mathrm{p} 4$ \\
$1718 / 2 \times 1716 / 10 / /^{\mathrm{b}}$ & $2 / / 3$ & $0 / / 0$ & $-/ /-$ & $\mathrm{p} 4 / / \mathrm{p} 4$ \\
$1718 / 2 \times 1716 / 30 / /^{\mathrm{b}}$ & $5 / / 5$ & $0 / / 0$ & $-/ /-$ & $\mathrm{p} 4 / / \mathrm{p} 4$ \\
$1718 / 3 \times 1716 / 30 / /^{\mathrm{b}}$ & $\mathrm{nd}$ & $0 / / 5$ & $-/ / 225+314+283+276+285$ & $\mathrm{p} 4 / / \mathrm{p} 4$ \\
$1718 / 4 \times 1716 / 42 / /^{\mathrm{b}}$ & $5 / / 5$ & $5 / / 0$ & $21+28+36+57+48 / /-$ & $\mathrm{p} 4 / / \mathrm{p} 4$ \\
$1718 / 4 \times 1716 / 51 / /^{\mathrm{b}}$ & $5 / / 6$ & $3 / / 5$ & $99+62+150 / / 57+222+230+77+224$ & $\mathrm{p} 4 / / \mathrm{p} 4$ \\
$1718 / 5 \times 716 / 42 / /^{\mathrm{b}}$ & $3 / / 5$ & $0 / / 0$ & $-/ /-$ & $\mathrm{p} 4 / / \mathrm{p} 4$ \\
$1718 / 5 \times 1716 / 51 / /^{\mathrm{b}}$ & $6 / / 6$ & $1 / / 2$ & $74 / / 211+241$ & $\mathrm{p} 4 / / \mathrm{p} 4$ \\
$1718 / 6 \times 1716 / 10 / /^{\mathrm{b}}$ & $5 / / 6$ & $3 / / 3$ & $83+25+33 / / 280+129+150$ & $\mathrm{p} 4 / / \mathrm{p} 4$ \\
\hline
\end{tabular}

CII $1718 \times$ CII 1716 crosses

nd no data

${ }^{\text {a }}$ Pollen tube growth until the base of the style (p4)

b Reciprocal crosses

Table 10 Number of pollinated flowers, fruits and seeds per fruit in interspecific crosses in S. infundibuliforme $\times$ S. oplocense reciprocal genotypic combinations

\begin{tabular}{lllll}
\hline Genotypic combinations & Pollinated flowers & Fruits & Seeds/fruit & $\begin{array}{l}\text { Pollen-pistil } \\
\text { relations }\end{array}$ \\
\hline $1715 / 2 \times 1705 / \mathrm{A} 1 / /^{\mathrm{b}}$ & $4 / / 2$ & $0 / / 0$ & $-/ /-$ & $\mathrm{p} 4 / / \mathrm{p} 4$ \\
$1715 / 2 \times 1705 / \mathrm{B} 6 / /^{\mathrm{b}}$ & $5 / / 4$ & $0 / / 0$ & $-/ /-$ & $\mathrm{p} 4 / / \mathrm{p} 4$ \\
$1715 / 20 \times 1705 / \mathrm{A} 14 / /^{\mathrm{b}}$ & $5 / / 5$ & $0 / / 0$ & $-/ /-$ & $\mathrm{p} 4 / / \mathrm{p} 4$ \\
$1715 / 20 \times 1706 / \mathrm{B} 4 / /^{\mathrm{b}}$ & $3 / / 2$ & $0 / / 0$ & $-/ /-$ & $\mathrm{p} 4 / / \mathrm{p} 3$ \\
$1715 / 37 \times 1706 / \mathrm{B} 3 / /^{\mathrm{b}}$ & $5 / / 5$ & $0 / / 0$ & $-/ /-$ & $\mathrm{p} 4 / / \mathrm{p} 3$ \\
$1715 / 37 \times 1706 / \mathrm{B} 4 / /^{\mathrm{b}}$ & $3 / / 3$ & $3 / / 0$ & $0+0+0 / /-$ & $\mathrm{p} 4 / / \mathrm{p} 4$ \\
$1715 / 37 \times 1706 / \mathrm{H} 7 / /^{\mathrm{b}}$ & $5 / / 5$ & $0 / / 0$ & $-/ /-$ & $\mathrm{p} 3 / / \mathrm{p} 3$ \\
$1715 / 38 \times 1706 / \mathrm{F} 10 / /^{\mathrm{b}}$ & $2 / / 3$ & $1 / / 0$ & $0 / /-$ & $\mathrm{p} 4 / / \mathrm{p} 4$ \\
$1715 / 38 \times 1706 / \mathrm{B} 21 / /^{\mathrm{b}}$ & $6 / / 5$ & $0 / / 0$ & $-/ /-$ & $\mathrm{p} 4 / / \mathrm{p} 4$ \\
$1715 / 38 \times 1705 / \mathrm{A} 4$ & 3 & 3 & $0+(1+\mathrm{ES})+(2+\mathrm{ES})$ & $\mathrm{p} 4$ \\
$1715 / 53 \times 1706 / \mathrm{F} 3 / /^{\mathrm{b}}$ & $4 / / 4$ & $1 / / 0$ & $0 / /-$ & $\mathrm{p} 4 / / \mathrm{p} 4$ \\
$1715 / 57 \times 1706 / \mathrm{H} 7 / /^{\mathrm{b}}$ & $4 / / 3$ & $3 / / 0$ & $0+0+(4+\mathrm{ES}) / /-$ & $\mathrm{p} 4 / / \mathrm{p} 4$ \\
$1715 / 57 \times 1705 / \mathrm{A} 14 / /^{\mathrm{b}}$ & $3 / / 5$ & $2 / / 0$ & $0+0 / /-$ & $\mathrm{p} 4 / / \mathrm{p} 4$ \\
$1715 / 58 \times 1705 / \mathrm{B} 21 / /^{\mathrm{b}}$ & $6 / / 6$ & $4 / / 0$ & $0+0+0+1 / /-$ & $\mathrm{p} 4 / / \mathrm{p} 3$ \\
\hline
\end{tabular}

\section{ClI $1715 \times$ ClI 1705-CII 1706 crosses}

ES empty seeds

${ }^{a}$ Pollen tube inhibition in the second third of the style (p3); pollen tube growth until the base of the style (p4)

b Reciprocal crosses

encountered in morphological phenotypes and chromosome numbers, as well as on the reproductive behaviour and going-on gene flow at the site.
Quebrada de Inca Cueva $\left(23^{\circ} 00^{\prime} \mathrm{S}-65^{\circ} 28^{\prime} \mathrm{W}\right)$ is an $8 \mathrm{~km}$ long valley that covers a total area of $226.5 \mathrm{~km}^{2}$, reaching the eastern edge of the Argentinian Puna. It is 
Table 11 Number of pollinated flowers, fruits and seeds per fruit in interspecific crosses in S. infundibuliforme $\times$ S. oplocence reciprocal genotypic combinations

\begin{tabular}{|c|c|c|c|c|}
\hline Genotypic combinations & $\begin{array}{l}\text { Pollinated } \\
\text { flowers }\end{array}$ & Fruits & Seeds/fruit & $\begin{array}{l}\text { Pollen-pistil } \\
\text { relations }^{\text {a }}\end{array}$ \\
\hline $1717 / 3 \times 1705 / \mathrm{B} 21 / /^{\mathrm{b}}$ & $5 / / 2$ & $0 / / 0$ & $-1 /-$ & $\mathrm{p} 4 / / \mathrm{p} 4$ \\
\hline $1717 / 3 \times 1705 / \mathrm{B} 6 / /^{\mathrm{b}}$ & $5 / / 4$ & $4 / / 0$ & $0+0+15+16 / /-$ & $\mathrm{p} 4 / / \mathrm{p} 3$ \\
\hline $1717 / 3 \times 1706 / \mathrm{B} 3 / /^{\mathrm{b}}$ & $3 / / 3$ & $1 / / 0$ & $3 / /-$ & $\mathrm{p} 3 / / \mathrm{p} 3$ \\
\hline $1717 / 3 \times 1706 / \mathrm{F} 3 / /^{\mathrm{b}}$ & $3 / / 3$ & $2 / / 0$ & $0+1 / /-$ & $\mathrm{p} 4 / / \mathrm{p} 3$ \\
\hline $1717 / 3 \times 1706 / \mathrm{F} 7 / /^{\mathrm{b}}$ & $2 / / 4$ & $0 / / 0$ & $-/ /-$ & $\mathrm{p} 4 / / \mathrm{nd}$ \\
\hline $1717 / 4 \times 1706 / \mathrm{F} 3 / /^{\mathrm{b}}$ & $4 / / 3$ & $0 / / 0$ & $-1 /-$ & $\mathrm{p} 4 / / \mathrm{p} 1$ \\
\hline $1717 / 4 \times 1705 / \mathrm{B} 21$ & $3 / / 4$ & $2 / / 0$ & $0+0 / /-$ & $\mathrm{p} 4 / / \mathrm{p} 1$. \\
\hline $1717 / 8 \times 1705 / \mathrm{B} 21 / /^{\mathrm{b}}$ & $5 / / 4$ & $4 / / 0$ & $0+0+0+2 / /-$ & $\mathrm{p} 4 / / \mathrm{p} 1$ \\
\hline $1717 / 8 \times 1706 / \mathrm{F} 3$ & 2 & 2 & $0+0$ & $\mathrm{p} 4$ \\
\hline $1717 / 8 \times 1706 / \mathrm{D} 3 / /^{\mathrm{b}}$ & $4 / / 4$ & $0 / / 0$ & $-/ /-$ & $\mathrm{p} 4 / / \mathrm{p} 3$ \\
\hline $1717 / 10 \times 1706 / \mathrm{A} 18 / /^{\mathrm{b}}$ & $5 / / 5$ & $2 / / 0$ & $0+0 / /-$ & $\mathrm{p} 4 / / \mathrm{p} 3$ \\
\hline $1717 / 10 \times 1706 / \mathrm{D} 6 / /^{\mathrm{b}}$ & $3 / / 5$ & $2 / / 0$ & $0+0 / /-$ & $\mathrm{p} 4 / / \mathrm{nd}$ \\
\hline $1717 / 11 \times 1706 / \mathrm{D} 6 / /^{\mathrm{b}}$ & $5 / / 4$ & $0 / / 0$ & $-/ /-$ & $\mathrm{p} 4 / / \mathrm{p} 3$ \\
\hline $1717 / 11 \times 1706 / \mathrm{B} 4 / /^{\mathrm{b}}$ & $2 / / 6$ & $0 / / 0$ & $-1 /-$ & $\mathrm{p} 4 / / \mathrm{p} 4$ \\
\hline $1717 / 11 \times 1706 / \mathrm{F} 3$ & 6 & 5 & $0+0+0+0+0$ & $\mathrm{p} 4$ \\
\hline $1717 / 12 \times 1706 / \mathrm{D} 4 / /^{\mathrm{b}}$ & $4 / / 5$ & $0 / / 0$ & $-1 /-$ & $\mathrm{p} 3 / / \mathrm{p} 1$ \\
\hline
\end{tabular}

ClI $1717 \times$ ClI 1705-CII 1706 crosses

nd no data

${ }^{\text {a }}$ Pollen grains of heterogeneous size that did not fluoresce or geminate on the stigma in addition to inhibition pollen tube growth at the first third of style (p1); pollen tube inhibition in the second third of the style (p3); pollen tube growth until the base of the style (p4)

b Reciprocal crosses

Table 12 Number of pollinated flowers, fruits and seeds per fruit in interspecific crosses in $S$. gourlayi $\times$ S. oplocence reciprocal genotypic combinations

\begin{tabular}{lllll}
\hline Genotypic combinations & Pollinated flowers & Fruits & Seeds/fruit & $\begin{array}{l}\text { Pollen-pistil } \\
\text { relations }\end{array}$ \\
\hline $1718 / 1 \times 1705 / \mathrm{A} 4 / /^{\mathrm{b}}$ & $4 / / 4$ & $0 / / 0$ & $-/ /-$ & $\mathrm{p} 4 / / \mathrm{p} 4$ \\
$1718 / 1 \times 1705 / \mathrm{E} 1 / /^{\mathrm{b}}$ & $\mathrm{nd}$ & $0 / / 0$ & $-/ /-$ & $\mathrm{p} 2 / / \mathrm{p} 1$ \\
$1718 / 3 \times 1706 / \mathrm{D} 6 / /^{\mathrm{b}}$ & $6 / / 5$ & $2 / / 0$ & $17 \mathrm{ES}+174 / /-$ & $\mathrm{p} 4 / / \mathrm{p} 1$ \\
$1718 / 3 \times 1706 / \mathrm{E} 1 / /^{\mathrm{b}}$ & $\mathrm{nd}$ & $0 / / 0$ & $-/ /-$ & $\mathrm{p} 4 / / \mathrm{p} 1$ \\
$1718 / 4 \times 1706 / \mathrm{D} 6 / /^{\mathrm{b}}$ & $5 / / 5$ & $4 / / 0$ & $(35+\mathrm{ES})+(37+\mathrm{ES})+(74+\mathrm{ES})+(24+\mathrm{ES}) / /-$ & $\mathrm{p} 4 / / \mathrm{p} 1$ \\
$1718 / 4 \times 1706 / \mathrm{F} 7 / /^{\mathrm{b}}$ & $5 / / 5$ & $0 / / 0$ & $-/ /-$ & $\mathrm{p} 5 / / \mathrm{p} 1$ \\
$1718 / 5 \times 1706 / \mathrm{D} 6 / /^{\mathrm{b}}$ & $5 / / 5$ & $0 / / 0$ & $-/ /-$ & $\mathrm{p} 4 / / \mathrm{p} 1$ \\
$1718 / 5 \times 1706 / \mathrm{F} 7 / /^{\mathrm{b}}$ & $5 / / 5$ & $0 / / 0$ & $-/ /-$ & $\mathrm{nd} / / \mathrm{p} 1$
\end{tabular}

CII $1718 \times$ CII 1706-CII 1705 crosses

nd no data, ES empty seeds

${ }^{a}$ Pollen grains of heterogeneous size that did not fluoresce or geminate on the stigma in addition to inhibition pollen tube growth at the first third of style (p1); pollen tube inhibition in the first third of the style (p2); pollen tube growth until the base of the style (p4); pollen did not germinate in the stigma (p5)

b Reciprocal crosses 
Table 13 Number of pollinated flowers, fruits and seeds per fruit in interspecific crosses in S. gourlayi $\times$ S. oplocense reciprocal genotypic combinations

\begin{tabular}{|c|c|c|c|c|}
\hline Genotypic combinations & $\begin{array}{l}\text { Pollinated } \\
\text { flowers }\end{array}$ & Fruits & Seeds/fruit & $\begin{array}{l}\text { Pollen-pistil } \\
\text { relations }^{\mathrm{a}}\end{array}$ \\
\hline $1710 / 7 \times 1706 / \mathrm{F} 3 / /^{\mathrm{b}}$ & $4 / / 4$ & $4 / / 0$ & $(3+\mathrm{ES})+(3+\mathrm{ES})+(5+\mathrm{ES})+\mathrm{ES} / /-$ & $\mathrm{p} 4 / / \mathrm{nd}$ \\
\hline $1710 / 7 \times 1706 / \mathrm{D} 6 / /^{\mathrm{b}}$ & $2 / / 5$ & $2 / / 0$ & $(1+\mathrm{ES})+(5+\mathrm{ES}) / /-$ & $\mathrm{p} 4 / / \mathrm{p} 4$ \\
\hline $1710 / 11 \times 1706 / \mathrm{D} 3 / /^{\mathrm{b}}$ & $5 / / 5$ & $4 / / 0$ & $(6+\mathrm{ES})+(28+\mathrm{ES})+(12+\mathrm{ES})+(25+\mathrm{ES}) / /-$ & $\mathrm{p} 4 / / \mathrm{p} 4$ \\
\hline $1710 / 11 \times 1706 / \mathrm{A} 18 / /^{\mathrm{b}}$ & $5 / / 5$ & $3 / / 0$ & $(40+\mathrm{ES})+(16+\mathrm{ES})+(15+\mathrm{ES}) / /-$ & $\mathrm{p} 4 / / \mathrm{p} 3$ \\
\hline $1710 / 14 \times 1706 / \mathrm{A} 18 / /^{\mathrm{b}}$ & $4 / / 4$ & $1 / / 0$ & $80 \mathrm{ES} / /-$ & $\mathrm{p} 4 / / \mathrm{p} 3$ \\
\hline $1710 / 14 \times 1706 / \mathrm{D} 6 / /^{\mathrm{b}}$ & $2 / / 5$ & $1 / / 0$ & $(25+\mathrm{ES}) / /-$ & $\mathrm{p} 4 / / \mathrm{p} 3$ \\
\hline $1710 / 14 \times 1705 / \mathrm{A} 8 / /^{\mathrm{b}}$ & $3 / / 3$ & $1 / / 0$ & $0 / /-$ & $\mathrm{p} 4 / / \mathrm{p} 4$ \\
\hline $1710 / 17 \times 1706 / \mathrm{A} 18$ & 5 & 2 & $(4+E S)+(6+E S)$ & $\mathrm{p} 4$ \\
\hline $1710 / 17 \times 1705 / \mathrm{B} 21 / /^{\mathrm{b}}$ & $4 / / 5$ & $2 / / 2$ & $50 \mathrm{ES}+7 / / 9+15$ & $\mathrm{p} 4 / / \mathrm{p} 4$ \\
\hline $1710 / 17 \times 1706 / \mathrm{D} 6 / /^{\mathrm{b}}$ & $5 / / 6$ & $1 / / 0$ & $(6+50 \mathrm{ES}) / /-$ & $\mathrm{p} 4 / / \mathrm{p} 3$ \\
\hline $1710 / 17 \times 1705 / \mathrm{B} 6$ & $3 / / 5$ & $2 / / 1$ & $(10+\mathrm{ES})+(1+\mathrm{ES}) / / 17$ & $\mathrm{p} 4 / / \mathrm{p} 3$ \\
\hline $1710 / 19 \times 1706 / \mathrm{B} 3 / /^{\mathrm{b}}$ & $2 / / 3$ & $2 / / 0$ & $39+51 / /-$ & $\mathrm{p} 4 / / \mathrm{nd}$ \\
\hline $1710 / 19 \times 1706 / \mathrm{B} 4 / /^{\mathrm{b}}$ & $3 / / 6$ & $3 / / 0$ & $(6+\mathrm{ES})+(43+\mathrm{ES})+24 \mathrm{ES} / /-$ & $\mathrm{p} 4 / / \mathrm{p} 4$ \\
\hline $1710 / 19 \times 1705 / \mathrm{B} 6 / /^{\mathrm{b}}$ & $5 / / 2$ & $2 / / 0$ & $(26+\mathrm{ES})+(2+\mathrm{ES}) / /-$ & $\mathrm{p} 4 / / \mathrm{p} 3$ \\
\hline $1710 / 19 \times 1705 / \mathrm{B} 21 / /^{\mathrm{b}}$ & $5 / / 2$ & $2 / / 0$ & $(15+\mathrm{ES})+(14+\mathrm{ES}) / /-$ & $\mathrm{p} 4 / / \mathrm{nd}$ \\
\hline $1710 / 21 \times 1706 / \mathrm{B} 3 / /^{\mathrm{b}}$ & $3 / / 5$ & $2 / 0$ & $4+(1+\mathrm{ES}) / /-$ & $\mathrm{p} 4 / / \mathrm{p} 4$ \\
\hline $1710 / 21 \times 1705 / \mathrm{A} 8 / /^{\mathrm{b}}$ & $2 / / 4$ & $1 / / 2$ & $9 / / 94+2$ & $\mathrm{p} 4 / / \mathrm{p} 4$ \\
\hline $1710 / 21 \times 1706 / \mathrm{B} 5 / /^{\mathrm{b}}$ & $2 / / 6$ & $1 / / 0$ & $(11+\mathrm{ES}) / /-$ & $\mathrm{p} 4 / / \mathrm{p} 4$ \\
\hline
\end{tabular}

CII $1710 \times$ ClI 1706-CII 1705 crosses

ES empty seeds, $n d$ no data

${ }^{\text {a }}$ Pollen tube inhibition in the second third of the style (p3); pollen tube growth until the base of the style (p4)

b Reciprocal crosses

dominated by red sedimentary sandstones, irrigated along its south-north emplacement by the Chulín River. Many caves or sites have been detected along the valley with carved and painted anthropomorphic and zoomorphic figures on red limestones, revealing the presence of pre-Columbian inhabitants (Rolandi et al. 2004).

Three distinct phytogeographic provinces meet in the area: Prepuneña, Puneña and Altoandina, according to Cabrera and Willink (1980). The characteristic stone red walls, as well as large stone formations that accumulate water, create a particular environment. Common plant species found in the area are: Satureja parviflora (Phil.) Epling ("muña-muña"), Cortaderia rudiuscula Stapfl. ("pampa grass"), Parastrephia quadrangularis (Meyen) Cabrera ("tola"), Baccharis grisebachii Hieron., Polylepis tomentella Weddell ("queñoa") and Trichocereus tarijense (Vaupel) Werderm. (“cardón”) (Ruthsatz and Movia 1975).
The Quebrada de Inca Cueva has been visited over the years by several botanists, who collected various wild potato species. W. Hoffmann collected S. gourlayi in 1972; K. A. Okada collected grl, ifd, S. acaule Bitt. (acl) and S. megistacrolobum Bitt. (mga) in 1978; A. M. Clausen and V.N. Ispizúa collected grl, ifd, presumed grl-ifd hybrids and mga in 2005, and V.N. Ispizúa and A. Stabile collected ifd, acl, "acl-mga" and opl in 2008.

Diploid and polyploid potatoes can reproduce sexually by seeds and asexually by stolons and tubers, but the extent of each type of reproduction in nature is not known. River and water courses, anthropic activities, grazing animals and birds contribute to seed dispersal, providing opportunities for gene flow. As an example, in Quebrada de Humahuaca (Argentina), we observed plants of $S$. oplocense atypically growing on a $1 \mathrm{~m}$ high trunk of Prosopis ferox Griseb. Another example was provided by Okada and Clausen (1982, 1985) who found large populations of wild potatoes, 
including natural hybrids, frequently growing within enclosures surrounded by stone fences where the cattle gather at night. This is the result of the intensive grazing carried out by goats, sheep, cattle and camelids and the fact that potato seeds are not affected by the passage through the digestive tract of animals, which contribute to the dispersion of wild potato species.

Potato species possess a gametophytic self-incompatibility system controlled by one multiallelic S-locus which prevents fertilisation if there is identity between $\mathrm{S}$-alleles carried by pollen and pistil. Whereas diploids are obligate outcrossers (allogamous), polyploids can also self-pollinate because the incompatibility reaction is suppressed in pollen grains carrying different $\mathrm{S}$-alleles, due to a phenomenon known as competitive interaction (Frankel and Galum 1977). Natural pollination in potatoes is entomophilous, being main flower visitors are species of Bombus ("bumblebees") that can typically forage over 100-1750 m (Walther-Hellwig and Frankl 2000).

In nature, wild potatoes are isolated by external geographical and ecological hybridisation barriers (Hawkes and Hjerting 1969), reinforced by internal pre- and post-zygotic barriers. Pre-zygotic barriers act at the pollen-pistil level (a phenomenon known as either cross-incompatibility or incongruity) (Camadro and Peloquin 1981; Sala 1993; Camadro et al. 1998; Ispizúa et al. 1999; Raimondi and Camadro 2003) and can be either unilateral or bilateral. Post-zygotic barriers act mainly at the endosperm level, although embryo abortion, male sterility, weakness or sterility of the $F_{1}$ and/or $F_{2}$ and/or advanced segregating progenies has been reported (Camadro et al. 2004). Internal barriers are under genetic control. Regarding the endosperm barrier, Johnston et al. (1980) have proposed the Endosperm Balance Number (EBN) hypothesis, according to which potatoes have a real ploidy (given by their actual chromosome numbers) and an 'effective' ploidy resulting from the action of hypothetical genetic factors. On the basis of controlled crosses with a species taken as standard, potato species were assigned one, two or four EBN (Johnston and Hanneman 1980). For normal endosperm development, a two (female) to one (male) EBN ratio in the endosperm is required. Thus, in otherwise pollenpistil compatible genotypic combinations, the EBN acts as a screen, allowing hybridization if both parents, regardless of their ploidy, produce gametes with the same EBN or, if their EBNs differ, when the parent with the lowest EBN produces $2 n$ gametes. These numerically unreduced gametes ( $2 \mathrm{n}$ eggs) or gametophytes ( $2 \mathrm{n}$ pollen) can be the result of genetically controlled abnormalities in meiosis, among other cytological events (Mok and Peloquin 1975; Camadro and Peloquin 1980). Consequently, their formation can be a recurrent process. $2 n$ gametes provide the opportunity for unilateral and bilateral sexual polyploidization, in both breeding and evolution, and introgression between different ploidy levels (Mendiburu and Peloquin 1976; den Nijs and Peloquin 1977).

In our study, all the populations grouped according to their chromosome number in the multivariate analysis. Tetraploid populations belonging to presumed hybrids and grl formed a huge swarm in which individuals from different populations appeared intermixed. In accession CII 1715, a huge variation in morphological phenotypes in diploid and tetraploid plants was observed, as well as individuals with intermediate characters between the putative parents, which is a strong indication of the presence of hybrid complexes. The collection site of this accession was a sandy beach, situated between Chulín River and a stream emerging from a narrow gorge parallel to the Quebrada de Inca Cueva. It is likely that this population is composed of individuals that have hybridized either somewhere in the "Quebrada" and were transported by the water to the sandy microsite, or they could be the result of hybridization at the microsite. Furthermore, as we sampled only vegetative material, the collected plantlets are considered to be a good sample of the genotypes present in the population at the time of collection. The others accessions classified as "tetraploid presumed hybrids" resembled S. gourlayi in their general appearance, but the decurrency and dimensions of the lateral leaflets suggest introgression from $S$. infundibuliforme.

In our present work, results of crosses within accessions of $S$. infundibuliforme and $S$. gourlayi presented a high percentage of compatible combinations and a large number of pollen tubes reached the base of the style. Seed set was in agreement with the expected according to pollen-pistil reactions and to intraspecific controlled crosses carried routinely out in the genebank in Balcarce, in which, most frequently, the number of seeds/fruit range from 50 to 300 (Digilio pers comm.). 
In crosses between accessions identified as $S$. infundibuliforme (CII 1715 and CII 1717) and tetraploid presumed hybrid (CII 1716, CII 1711), different sites of pollen tube inhibition and problems in seed set were detected. In certain genotypic combinations in which many pollen tubes were observed at the base of the style, we obtained fruits with empty or small seeds and seedless fruits. This indicated the action of postzygotic barriers triggering seed abortion by dysfunction of endosperm, embryo, or both tissues, as observed in other interspecific crosses in potato (Masuelli and Camadro 1997). These barriers could result from differences in the EBN of the uniting gametes or other genetic problems. Only one genotypic combination $($ ClI $1715 / 52 \times 1711 / 6)$ produced two fruits with 55 and 79 seeds respectively. The derived offspring was tetraploid, a fact that could be explained by assuming that the diploid female parent produced functional $2 \mathrm{n}$ eggs which allowed the circumvention of the EBN barrier in the inter-EBN combination.

Larrosa et al. (2012) reported the presence of heterogeneous size pollen in six accessions from Quebrada de Inca Cueva (CII 1710, ClI 1707, CII 1716, CII 1712, CII 1715, CII 1717) that were also used in the present study. They observed pollen grains varied in diameters from smaller than the expected for normal $\mathrm{n}$ up to the expected for $4 \mathrm{n}$, except for one populations (CII 1717), which did not have pollen in the smaller size class. Accessions CII 1707, CII 1716, CII 1717 had relatively low average pollen viability $(67.3,57.6$ and $59.7 \%$, respectively). Additionally, CII 1716 exhibited the highest percentages of $<\mathrm{n}$ pollen grains $(15.6 \%)$ and the highest average percentage of pollen in the 'lacking' protoplasm category. The authors concluded that the cytological observations in CII 1716 provided additional evidence on its putative hybrid origin, although the occurrence of intra-specific polyploids cannot be discarded since plants of this accession and of other accessions from Inca Cueva produced $>\mathrm{n}$ pollen, as well as the expected $n$ pollen.

In crosses between accessions of $S$. gourlayi and tetraploid presumed hybrids, normal pollen tube growth down to the base of the style was observed in both directions, in all genotypic combinations. The number of seed/fruits was the expected for genetic combinations in which both parents have the same $\mathrm{EBN}$, and is in accordance with the microscopic observations.
In interspecific crosses between of $S$. infundibuliforme from Quebrada de Inca Cueva (CII 1715 and CII 1717) and S. oplocense from Coctaca, three sites of pollen-pistil incompatibility were observed, as well as the phenomena of unilateral incompatibility (UI) and bilateral incompatibility (BI). Some genotypes presented different incompatibility sites depending on the genotype of the other parent involved in the cross. From the crossing results, it is apparent that post-zygotic barriers are operating between these accessions because fruits with either few or empty seeds, as well as seedless fruits, were obtained. It is expected that a barrier of this sort is acting between these accessions because the species involved have different EBN: ifd has been assigned 2 EBN whereas opl has been assigned 4 EBN. In grl-opl crosses, four sites of pollen-pistil incompatibility were observed. Moreover, in combinations in which many pollen tubes were observed at the base of the style, only fruits with empty seeds or fruits with a few normal seeds in addition to empty seeds were produced. This indicates the action of internal hybridization barriers at more than one level: inhibition of pollen tube growth in the style, and either prevention of syngamy or abnormal embryo/ endosperm development if syngamy had occurred. These barriers were incomplete as normal seeds were obtained in certain genotypic combinations and the chromosome number of a sample of seedlings was pentaploid $(2 \mathrm{n}=5 \mathrm{x}=60)$. Furthermore, in ClI 1706-CII $1705 \times$ CII 1718 crosses, pollen grains of variable size and morphology that did not fluoresce were observed. Larrosa et al. (2012) had reported the presence of shrunken pollen grains, with tri-lobulated shape and heterogeneous size, in six populations sampled from Quebrada de Inca Cueva, and we observed a similar situation in CII 1718 from the same site.

The action of genes independent of the $\mathrm{S}$ locus would explain the expression of several sites of pollen-pistil incompatibility after interspecific pollinations. This phenomenon of cross-incompatibility was initially proposed by Grun and Radlow (1961) and later by Camadro and Peloquin (1981), Camadro et al. (1998), Erazzú et al. (1999), Raimondi and Camadro (2003), among others. The results of the present work in grl-opl crosses are similar to the reported by Camadro and Peloquin (1980), who proposed a genetic model with dominant CI genes in styles that prevented fertilization by pollen carrying specific dominant complementary genes, which was based on the model of incongruency developed by 
Hogenboom (1973). This model, which assumes segregation for both type of loci, accounts for the results of both UI and BI incompatibility in inter- and intraspecific crosses in tuber-bearing Solanum (Camadro et al. 2004).

Interspecific hybridization may have several evolutionary consequences, including increased intraspecific genetic diversity, the origin of new species, and the reinforcement of reproductive barriers (Rieseberg 1997; Barton 2001). In diploid and tetraploid potatoes, it is likely that more than one of these events had taken place during the evolution as reported by many authors (Okada and Clausen 1982, 1985; Spooner and van den Berg 1992; Erazzú et al. 2009; Bedonni and Camadro 2009) in overlapping areas. Erazzú et al. (2009) reported complex variation patterns for accessions of $S$. gourlayi and S. spegazzinii in a gorge in northwestern Argentina. These species have been reported as producing $2 \mathrm{n}$ gametes that are functional in fertilization. Hibridization and subsequent gene flow within and between ploidy levels mediated by $2 \mathrm{n}$ gametes often results in exceedingly complicated patterns of variation (Masuelli et al. 2009) as we observed in this study. Hybrids, if sterile, are maintained by asexual reproductions but, if they are partially or completely fertile, they can also reproduce sexually, interbreeding among them and with plants of the parental population. Thus, we suppose that the populations collected in Quebrada de Inca Cueva may be composed of a complex mixture of parental genotypes, first and advanced hybrid generations and backcrosses, with both types of reproduction, and overlapping in flowering. In this way, hybridization and introgression provide the means by which the genetic variability of populations in Quebrada de Inca Cueva is increased over time, also favored by the specific geographic characteristics of the place.

The results of this work have important implications for in situ and ex situ conservation of populations from Quebrada de Inca Cueva. We here provide evidence of the morphological variability encountered in the populations sampled in the area as well as the occurrence of the natural hybridization and gene flow. Considering recent anthropic activities occurring due to the establishment of a fence and public access through a wooden trail to the to the archeological site, it would be important to ensure the survival of these populations in situ and manage the Quebrada de Inca Cueva in such a way as to maintain the actual environmental conditions, and prevent or minimize future disturbances.
Considering that Inca Cueva includes a heritage site, this could be achieved with joint actions with the communal local authorities of the department of Humahuaca, with the archaeologist working in the area and with the national activities initiated in in situ conservation of crop wild relatives of Argentina (Atencio et al. 2011).

To continue with the systematic ex situ conservation and use of the wild potato gene pool in Argentina, it is crucial to consider the frequent phenomenon of hybridization that is occurring in many spontaneous populations. These hybrids may have intermediate traits from the parental species and/or exhibit particular adaptations to the environment. Furthermore as differential crossing behaviour and seed set was revealed in the populations studied this fact should be taken into account when selecting accessions for breeding purposes, increasing the efficiency of use of this germplasm. We consider that the gene pool concept could be applied in the populations sampled in Quebrada de de Incacueva. Hybrids as well as plants phenotypically resembling pure species are part of the same gene pool. Therefore, plants that are male and/or female fertile, regardless of their morphological phenotypes can be incorporated into cultivated potato breeding plans.

Acknowledgments This work was supported by the Instituto Nacional de Tecnología Agropecuaria (INTA) Projects Nos. 231211-231221 and by the Universidad Nacional de Mar del Plata (15/A304).

\section{References}

Alvarez NMB, Peralta I, Salas A, Spooner DM (2008) A morphological study of species boundaries of the wild potato Solanum brevicaule complex: replicated field trials in Peru. Plant Syst Evol 274:37-45

Atencio HM, Ispizúa VN, Clausen AM (2011) Caracterización morfológica y molecular de Solanum microdontum Bitt.: implicancias para su conservación in situ y ex situ. VIII Simposio Internacional de Recursos Genéticos para América Latina y El Caribe. Quito, Ecuador. 21 al 23 de noviembre de 2011

Barton NH (2001) The role of hybridization in evolution. Mol Ecol 10:551-568

Bedonni MC, Camadro EL (2009) Morphological and molecular evidence of natural interspecific hybridization in the diploid potato Solanum kurtzianum from Argentina. Botany $87: 78-87$

Brown AHD, Marshall DR (1995) A basic sampling strategy: theory and practice. In: Guarino L, Ramanatha Rao V, Reid $\mathrm{R}$ (eds) Collecting plant genetic diversity: technical guidelines. CAB International, Wallingford, UK, pp 75-91 
Cabrera AL, Willink A (1980) Biografía de América latina. OEA, Washington, DC

Camadro EL, Peloquin SJ (1980) The occurrence and frequency of $2 \mathrm{n}$ pollen in three diploid Solanum from Northwest Argentina. Theor Appl Genet 56:11-15

Camadro EL, Peloquin SJ (1981) Cross-incompatibility between two sympatric polyploidy Solanum species. Theor Appl Genet 60:65-70

Camadro EL, Verde LA, Marcellán ON (1998) Pollen-pistil incompatibility in a diploid hybrid potato population with cultivated and wild germplasm. Am J Potato Res 75:81-85

Camadro EL, Carputo D, Peloquin SJ (2004) Substitutes for genome differentiation in tuber-bearing Solanum: interspecific pollen-pistil incompatibility, nuclear-cytoplasmic male sterility, and endosperm. Theor Appl Genet 109:1369-1376

Clausen AM, Okada KA (1987) The subspecies of Solanum gourlayi Hawkes. Phytologia 62:165-170

Clausen AM, Spooner DM (1998) Molecular support for the hybrid origin of the wild potato species Solanum $\times$ rechei. Crop Sci 38:858-865

Clausen AM, Colovita M, Butzonitch I, Carranza AV (2005) A potato collecting expedition in the province of Jujuy, Argentina and disease indexing of virus and fungus pathogens in Andean cultivars. Genet Resour Crop Evol 52:1099-1109

Coleman LC (1938) Preparation of leucobasic fuchsin for use in the Feulgen's reaction. Stain Technol 13:123-124

Correll DS (1962) The potato and its wild relatives. Texas Research Foundation, Renner

den Nijs TP, Peloquin SJ (1977) 2n gametes in potato species and their function in sexual polyploidization. Euphytica 26:585-600

Di Rienzo JA, Casanoves F, Balzarini MG, Gonzalez L, Tablada M, Robledo CW (2008) InfoStat, versión 2008. FCA, Universidad Nacional de Córdoba, Argentina, Grupo InfoStat

Dionne LA (1958) 2,4-Dichlorophenoxyacetic acid as an aid to seed production when widely separated Solanum species are crossed. Nature 181:361

Erazzú LE, Camadro EL, Clausen AM (1999) Pollen-style compatibility relations in natural populations of the wild diploid potato species Solanum spegazzinii Bitt. Euphytica 105:219-227

Erazzú LE, Camadro EL, Clausen AM (2009) Persistence over time, overlapping distribution and molecular indications of interspecific hybridization in wild potato populations of Northwest Argentina. Euphytica 168:249-362

Frankel R, Galum E (1977) Pollination mechanisms, reproduction and plant breeding. Springer-Verlag, Heidelberg

Gower JC (1971) A general coefficient of similarity and some of its properties. Biometrics 27:857-874

Grun P, Radlow A (1961) Evolution of barriers to crossing of self-incompatibility with self-compatible species of Solanum. Heredity 16:137-143

Hawkes JG (1990) The potato: evolution, biodiversity and genetic resources. Belhaven Press, London

Hawkes JG, Hjerting JP (1969) The potatoes of Argentina, Brazil. Oxford University Press, Oxford, Paraguay and Uruguay. A biosystematic study

Hogenboom NG (1973) A model for incongruity in intimate partner relationships. Euphytica 22:219-233
Ispizúa VN, Camadro EL, Clausen AM (1999) Pre-zygotic breeding barriers between the wild diploid potato species Solanum maglia and S. kurtzianum from Argentina. Genet Resour Crop Evol 46:243-249

Johnston SA, Hanneman RE Jr (1980) Support of the endosperm balance number hypothesis utilizing some tuber-bearing Solanum species. Am Potato J 57:7-14

Johnston SA, den Nijs TPM, Peloquin SJ, Hanneman RE Jr (1980) The significance of genic balance to endosperm development in interspecific crosses. Theor Appl Genet 56:293-297

Larrosa FH, Maune JF, Erazzú LE, Camadro EL (2012) Meiotic abnormalities underlying pollen sterility in wild potato hybrids and spontaneous populations. Plant Biology 14:223-233

Martin FW (1958) Staining and observing pollen tubes in the style by means of fluorescence. Stain Tech 34:125-128

Masuelli RW, Camadro EL (1997) Crossability relationships among wild potato species with different ploidies and Endosperm Balance Number (EBN). Euphytica 94:227-235

Masuelli RW, Camadro EL, Erazzú LE, Bedogni MC, Marfil CF (2009) Homoploid hybridization in the origin and evolution of wild diploid species. Plant Syst Evol 277:143-151

Mendiburu AO, Peloquin SJ (1976) Sexual polyploidization and depolyploidization: some terminology and definitions. Theor Appl Genet 48:137-143

Miller JT, Spooner DM (1999) Collapse of species boundaries in the wild potato Solanum brevicaule complex (Solanaceae, S. sect. Petota): molecular data. Plant Syst Evol 214:103-130

Mok DWS, Peloquin SJ (1975) The inheritance of three mechanisms of diplandroid ( $2 \mathrm{n}$ pollen) formation in diploid potatoes. Heredity 35:295-302

Ochoa CM (1990) The potatoes of South America: Bolivia. Cambridge University Press, Cambridge

Okada KA, Clausen AM (1982) Natural hybridization between S. acaule Bitt and S. megistacrolobum Bitt. in the province of Jujuy, Argentina. Euphytica 31(3):817-835

Okada KA, Clausen AM (1985) Natural triploid between Solanum acaule Bitter and S. infundibuliforme Philippi in the province of Jujuy, Argentina. Euphytica 34:219-231

Okada KA, Hawkes JG (1978) Solanum $\times$ rechei, especie silvestre de papas de origen híbrido de la Sierra de Famatina (Provincia de la Rioja, Argentina). Kurtziana 11:55-74

Raimondi JP, Camadro EL (2003) Crossability relationships between the common potato, Solanum tuberosum L. ssp. tuberosum and its wild diploid relatives $S$. kurtzianum and S. ruiz-lealii. Genet Resour Crop Evol 50:307-314

Rieseberg LH (1997) Hybrid origins of plant species. Annu Rev Ecol Syst 28:359-389

Rodríguez F, Spooner DM (2009) Nitrate reductase phylogeny of potato (Solanum sect. Petota) genomes with emphasis on the origins of the polyploid species. Syst Bot 34:207-219

Rodríguez FM, Ghislain AM, Clausen SH, Jansky DM (2010) Hybrid origins of cultivated potatoes. Theor Appl Genet 121:1187-1198

Rolandi DS, Aschero C, Podestá MM, Re A (2004) Inca Cueva1: un siglo de aciertos y desaciertos en un sitio de alto valor patrimonial. In: Austral A, Tamagnini M (eds) Problemáticas de la Arqueología Contemporánea. Tomo 1. 
Universidad Nacional de Río Cuarto, Río Cuarto, pp 99-108

Ruthsatz B, Movia C (1975) Relevamiento de las estepas andinas del noreste de la provincia de Jujuy. República Argentina. Fundación para la educación, la ciencia y la cultura, Buenos Aires

Sala CA (1993) Incompatibilidad cruzada entre cinco especies tuberosas de Solanum (Solanaceae). Darwiniana 32:15-25

Spooner DM (2009) DNA barcoding will frequently fail in complicated groups: an example in wild potatoes. Am J Bot 96:1177-1189

Spooner DM, Hijmans RJ (2001) Potato systematics and germplasm collecting, 1989-2000. Am J Potato Res 78:237-268

Spooner DM, Salas A (2006) Structure, biosystematics, and genetic resources. In: Gopal J, Paul Khurana SM (eds) Handbook of potato production improvement, and postharvest management. Haworth's Press, Inc, Binghampton, pp 1-39

Spooner DM, van den Berg RG (1992) Species limits and hypotheses of hybridization of Solanum berthaultii
Hawkes and S. tarijense Hawkes: morphological data. Taxon 41:685-700

Spooner DM, van den Berg RG, Bryan G, del Rio A (2004) Species concepts and reduction of species in wild and cultivated potatoes (Solanum section Petota). Acta Hort 619:63-75

Spooner DM, Fajardo D, Bryan GJ (2007) Species limits of Solanum berthaultii Hawkes and S. tarijense Hawkes and the implications for species boundaries in Solanum sect. Petota. Taxon 56(4):987-999

Ugent D (1966) Hybrid weed complexes in Solanum, section Tuberarium. Ph.D. Diss, Univ. of Wisconsin, Madison, Wisconsin

Van den Berg RG, Miller JT, Ugarte ML, Kardolus JV, Nienhuis J, Spooner DM (1998) Collapse of morphological species in the wild potato Solanum brevicaule complex (Solanaceae: sect. Petota). Am J Bot 85:92-109

Walther-Hellwig K, Frankl R (2000) Foraging distances of Bombus muscorum, Bombus lapidarius, and Bombus terrestris (Hymenoptera, Apidae). J Insect Behav 13(2): 239-246 